\title{
Geology of the
}

\section{Norwood Quadrangle}

Norfolk and Suffolk

\section{Counties, Massachusetts}

By NEWTON E. CHUTE

- GEOLOGY OF SELECTED QUADRANGLES IN MASSACHUSETTS

GEOLOGICAL S UR VEY B ULLE TIN 1163-B

Prepared in cooperation with the Commonwealth of Massachusetts Department of Public Works

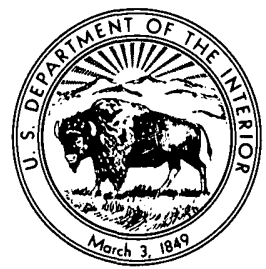




\section{UNITED STATES DEPARTMENT OF THE INTERIOR}

STEWART L. UDALL, Secretary

GEOLOGICAL SURVEY

William T. Pecora, Director 


\section{CONTENTS}

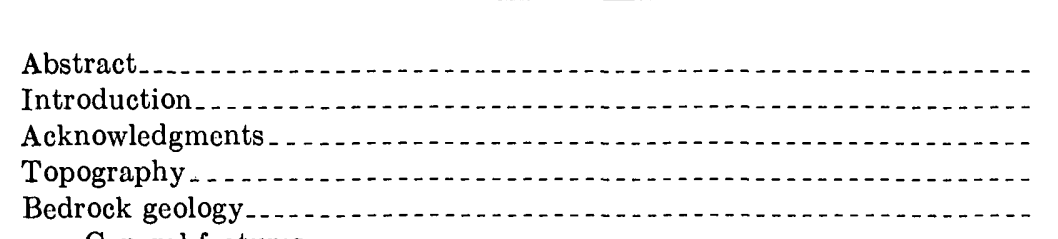

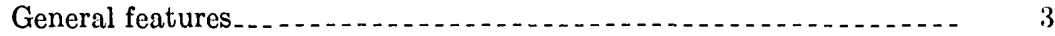

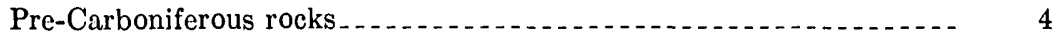

Metamorphic rocks ................... 4

Amphibolite and metarhyolite..... 4

Amphibolite

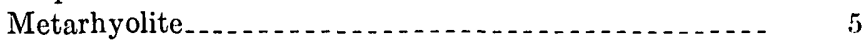

Green Lodge Formation of Rhodes and Graves (1931) _.... 7

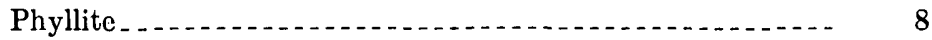

Igneous rocks .........

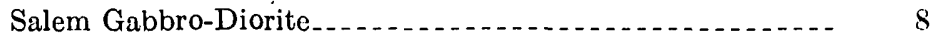

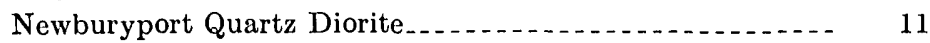

Dedham Granodiorite........... 12

Westwood Granite............ 14

Carboniferous or older igneous rocks . .

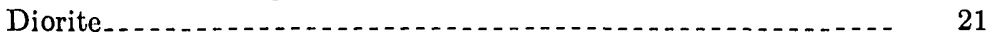

Sharon Syenite...... 22

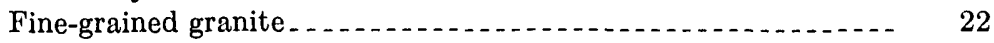

Aplite.............. 22

Devonian or Carboniferous rocks...

Igneous rocks . .

Mattapan Volcanic Complex......... 23

Gray felsites. . . .

Pink porphyritic rhyolite.

Pyroclastic rocks. .

Felsite dikes . .

Blue Hill Granite Porphyry

Sedimentary rocks..........

Roxbury Conglomerate........ 28

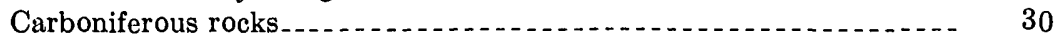

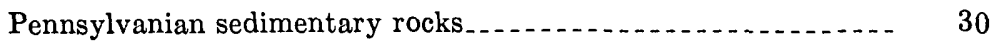

Pondville Conglomerate

Wamsutta Formation 32

Correlations............. 33

Dikes of diverse ages.......

Metamorphism_... 37

Structural geology

Folds......... 39

Faults

Joints... 43 
Surficial geology

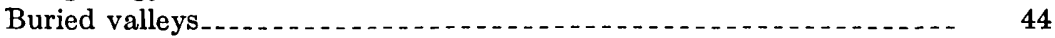

Glacial erosion . . . .

Glacial deposits . .

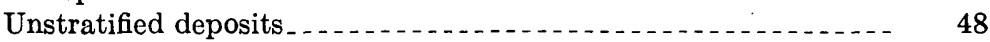

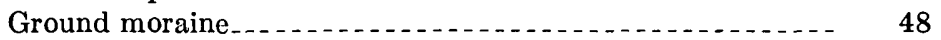

Drumlins. . .

Flowtill

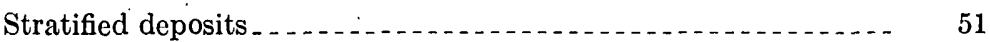

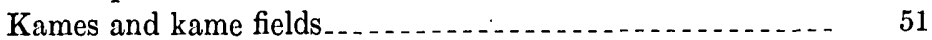

Ice-channel deposits . . . .

Kame terraces ...

Kame plains

Delta outwash plain

Alluvial fans

Outwash plains

Unclassified sand and gravel deposits..._._._._.

Varved lake clays....... 59

Eolian deposits

Weathering of the glacial deposits .

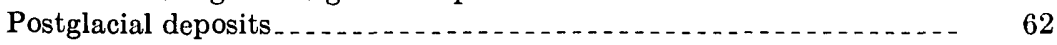

Swamp deposits

Artificial fill

Mineral resources.... 63

Sand and gravel........ 63

Loam

Peat..... 67

Diatomite

Building stone . .

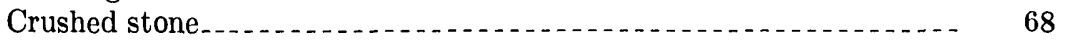

Geologic history

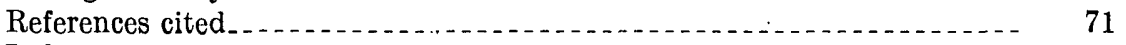

Index 


\section{ILLUSTRATIONS}

[Plates are in pocket]

Plate 1. Bedrock geologic map and sections.

2. Surficial geologic map.

Figures 1-5. Photographs of: Page

1. Pegmatitic Salem Gabbro-Diorite _.......... B9

2. Hybrid variety of Westwood Granite with inclusions of Salem Gabbro-Diorite.................... 17

3. Intrusion breccia formed by the Westwood Granite_ 18

4. Vertical Carboniferous metadiabase dike cutting a horizontal older spilitic diabase dike.......... $\quad 36$

5. Triassic diabase dike having columnar structure ... $\quad 37$

\section{TABLE}

TABLE

1. Materials found in selected borings in the Neponset River

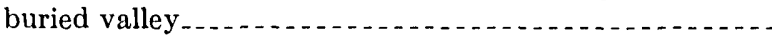





\title{
GEOLOGY OF SELECTED QUADRANGLES IN MASSACHUSETTS
}

\author{
GEOLOGY OF THE NORWOOD QUADRANGLE, \\ NORFOLK AND SUFFOLK COUNTIES, MASSACHUSETTS
}

\author{
By Newton E. Chute
}

\begin{abstract}
The Norwood 71/2-minute quadrangle, an area of about 55 square miles, southwest of Boston, Mass., has moderate relief and is drained mainly by the northeastward-flowing Neponset River. The bedrock is mostly igneous and sedimentary rocks. There are a few roof pendants or inclusions of metarhyolite and amphibolite of unknown age in the southeast corner, of quartzite and phyllite of the Cambrian Green Lodge Formation of Rhodes and Graves (1931) in the northeastern part, and of a phyllite of unknown but possible Cambrian age in the southwestern part. The area has four distinct groups of late Precambrian(?) and Paleozoic intrusive rocks which, from oldest to youngest, are (1) Salem Gabbro-Diorite, Newburyport Quartz Diorite, Dedham Granodiorite, and Westwood Granite, (2) diorite, Sharon Syenite, fine-grained granite, and aplite, (3) Blue Hill Granite Porphyry, and (4) diabase dikes. All these rocks are younger than the first regional metamorphism shown by the amphibolite and metarhyolite. Group (1) may be Precambrian or early to middle Paleozoic; group (2) is intermediate in age between groups (1) and (3); group (3) is Devonian or Carboniferous, and group (4) dikes are mostly Carboniferous, as many intrude the other Paleozoic igneous rocks and predate the late Paleozoic metamorphism, but some may be pre-Carboniferous. Olivine diabase dikes, considered to be Triassic, are the youngest of the igneous rocks. The Mattapan Volcanic Complex of flows, pyroclastics, dikes, and small plutons of Devonian or Carboniferous age is widespread in the northwestern part of the quadrangle. The Roxbury Conglomerate of Devonian or Carboniferous age underlies a small area in the northeastern part of the quadrangle. The Pondville Conglomerate and the Wamsutta Formation of Pennsylvanian age occupy the Norfolk basin, a faulted syncline that crosses the southern part of the quadrangle.

Two orogenies-one represented by northwest-trending structures in the amphibolite and metarhyolite and the other by northeastward-trending structures in the younger rocks-are recognized in the quadrangle. The Carboniferous basin sedimentary rocks were folded and much faulted during the second or Appalachian orogeny late in the Paleozoic. Of the faults inferred, two, one of which is known as the Stony Brook fault, have northward trends, and seven
\end{abstract}


others have more easterly trends. This second orogeny also caused low-grade regional metamorphism of the greenschist facies, best shown by the mafic rocks.

Glacial deposits cover much of the quadrangle area and include ground moraine, drumlins, kames, ice-channel fillings, kame terraces, kame plains, a delta outwash plain, outwash plains, and unclassified sand and gravel deposits. Recent deposits are thin and include swamp deposits and artificial fill.

The principal deposits of commercial value in the quadrangle are sand and gravel derived from the glacial deposits. Some of the bedrock formations are potential sources of building stone and crushed rock.

\section{INTRODUCTION}

The Norwood quadrangle comprises an area of about 55 square miles in eastern Massachusetts, southwest of Boston. It includes all of Norwood, part of the Hyde Park and Readville sections of Boston, and parts of Milton, Dedham, Westwood, Dover, Canton, Sharon, and Walpole. The Blue Star Memorial Highway (U.S. Route 1) crosses the quadrangle from north to south, and the Yankee Division Highway (State Route 128) crosses its northeastern part.

All the quadrangle except the northwest corner is drained by the Neponset River which flows northeast across the area to Dorchester Bay. The northwest corner is drained by streams that flow north to the Charles River. Glaciation disrupted the drainage, and many ponds and swamps still remain.

Wallace de Laguna mapped most of the bedrock outcrops in the west half of the quadrangle in the summer of 1939 for the U.S. Geological Survey. The writer mapped the glacial deposits and the bedrock of the entire quadrangle in 1940, using de Laguna's map, and examined the area briefly in the summers of 1957, 1958, and 1960 for new exposures. Work for this report was done in cooperation with the Massachusetts Department of Public Works.

\section{ACKNOWLEDGMENTS}

The assistance of those who have contributed to this report is gratefully acknowledged. Prof. Marland P. Billings of Harvard University gave valuable suggestions in the field and discussed geologic problems. Prof. Dirk de Waard of Syracuse University examined some thin sections and made helpful suggestions concerning the metamorphism. Mr. Norman P. Cuppels of the U.S. Geological Survey assisted in taking photographs. Miss M. Conant of the Dedham Historical Society provided information on the history of the pink Westwood Granite quarries in Dedham. The superintendents of the water departments of Dedham, Norwood, and Canton supplied information on the wells of their towns. The Massachusetts Department of Public Works made available aerial photographs and logs of borings. 


\section{TOPOGRAPHY}

The Norwood quadrangle is in the Seaboard Lowland section of the New England physiographic province and is characterized by low to moderate relief. Altitucies range from a minimum of about 35 feet above mean sea level along the Neponset River at the northeast corner of the quadrangle to a maximum of about 470 feet on Moose Hill at its south border.

The diversity of the topography is caused partly by the irregular configuration of the bedrock surface and partly by the varied glacial and postglacial deposits. Where outcrops are numerous, as in the northwestern part of the quadrangle, the bedrock largely determines the topography; where the glacial and postglacial deposits are thick and extensive, they cover the bedrock surface and partly or wholly determine the topography.

The history of the present bedrock topography may have begun in the Cretaceous Period or later, with the formation of an extensive erosional surface (peneplain), mostly of low relief but with a few residual hills, such as the Blue Hills to the east of the Norwood quadrangle (Davis, 1895, p. 269). Remnants of this erosion surface may be represented by the tops of the higher hills in the northwestern and southern parts of the quadrangle.

A belt of lower hills, about 5 miles wide, trends northeast across the quadrangle. These hills rise only about 200 feet above sea level and may be the remnants of an ancient valley floor formed during one of the incomplete cycles of erosion that dissected the older erosional surface. This valley is also dissected, but its walls are still fairly distinct in places. The northwest wall is best preserved along High Street between Westwood and the west edge of the quadrangle. The southeast wall is distinguishable from Canton southwestward to the corner of the quadrangle.

Uplift, probably late in the Tertiary Period, rejuvenated the streams and resulted in dissection that formed the younger bedrock valleys. This stream-eroded topography was modified somewhat by glacial erosion during the Pleistocene, but very little erosion of the bedrock has occurred since the last glaciation.

\section{BEDROCK GEOLOGY}

\section{GENERAL FEATURES}

Bedrock of the Norwood quadrangle consists of igneous, metamorphic, and sedimentary rocks ( $\mathrm{pl} .1$ ) that in most places are covered by a blanket of unconsolidated sediments deposited during Quaternary time (pl. 2). Igneous rocks underlie about three-fourths of the 
Norwood quadrangle, and sedimentary rocks underlie most of the rest; metamorphic rocks underlie only a few small highland areas.

Igneous rocks form most of the Needham upland in the northwestern part of the quadrangle and the Sharon upland in the southern part (LaForge, 1932, p. 8, fig. 3). The uplands reflect the resistance of the igneous rocks to erosion.

The sedimentary rocks are in structural basins of Carboniferous age. The Norfolk basin contains the Pondville Conglomerate and the Wamsutta Formation of Pennsylvanian age and is a downfolded trough $11 / 2^{-2}$ miles wide that extends northeast through the quadrangle. A downfaulted wedge in the northeastern corner of the quadrangle, representing a southern extension of the Boston basin, is underlain by the Roxbury Conglomerate of Devonian or Carboniferous age.

\section{PRE-CARBONIFEROUS ROCKS}

\section{METAMORPHIC ROCKS}

The pre-Carboniferous metamorphic rocks seem to be roof pendants or inclusions of formations that once covered the entire area but which have since been removed, in part by assimilation into the younger intrusive igneous rocks and in part by erosion. These metamorphic rocks include amphibolite and metarhyolite of unknown age, which may be part of the Marlboro Formation; quartzite and phyllite of the Green Lodge Formation of Rhodes and Graves (1931), of Upper Cambrian age; and phyllite of unknown age, which may be equivalent to part of the Green Lodge Formation.

\section{AMPHIBOLITE AND METARHYOLITE}

Several small areas of amphibolite and metarhyolite in and to the northeast of the center of Canton may correlate with the Marlboro Formation, considered to be of Precambrian age by Emerson (1917, p. 31) and LaForge (1932, p. 15). These rocks are intruded by the Salem Gabbro-Diorite and the Dedham Granodiorite, and they show an earlier metamorphism of higher grade than that shown by the other rocks of the quadrangle.

\section{AMPHIBOLITE}

Amphibolite crops out in two small areas in Canton, one on the east side of Pequid Brook near Reservoir Pond, the other about 1,500 feet to the southwest. Fragments of amphibolitized fine-grained basaltic rock have been found in an intrusion breccia formed by the Westwood Granite. This intrusion breccia is well exposed in places at the north edge of the quadrangle on the southeastbound lanes of Route 128 and 
nearby but is in bodies too small to map separately. It is also well exposed in the roadcuts on the northwestbound lanes of Route 128, about 800 and 1,800 feet north of the quadrangle boundary, in the Newton quadrangle. A porphyritic and a nonporphyritic amphibolite are present in exposures on the east side of Pequid Brook. They are interlayered, the layers ranging from about 8 to about 30 feet in thickness.

The porphyritic variety contains numerous thin tabular feldspar phenocrysts, a fraction of an inch to 2 inches in longest dimension, embedded in a fine-grained dark-greenish-gray matrix. The phenocrysts are alined and, in places, swirled. The matrix of the porphyritic variety consists of about 50 percent anhedral green hornblende, 20 percent zoisite, 20 percent feldspar, 10 percent sericite, 1 percent leucoxene, and a few grains of magnetite. The feldspar of the matrix is in such small grains and is so intermixed with the other minerals that it could not be satisfactorily identified, but it is probably albite. The phenocrysts are so highly altered to fine-grained zoisite and sericite that their original composition is unknown, but the abundance of zoisite indicates that they were calcic plagioclase.

The nonporphyritic variety of amphibolite is a greenish-gray somewhat foliated rock having numerous lens-shaped patches of darkgreen hornblende which average about a quarter of an inch long. The foliation strikes $\mathrm{N} .30^{\circ}-40^{\circ} \mathrm{W}$. and dips mostly $75^{\circ}-80^{\circ} \mathrm{SW}$.

This nonporphyritic variety is composed of about 50 percent hornblende, 40 percent highly altered feldspar, 10 percent chlorite, and minor amounts of leucoxene and epidote. About 20 percent of the hornblende occurs as short light-green anhedral grains concentrated in lenses ranging from 1 millimeter to 1 centimeter in greatest dimension. The rest of the hornblende is in smaller light-green anhedral grains scattered through the matrix. The feldspar in the matrix is in small untwinned anhedral grains. Alteration minerals, particularly sericite, are so abundant that the feldspar is difficult to identify. Optical data indicate that it is albite, although originally it was probably more calcic. The chlorite is in elongated patches in the matrix and contains much of the leucoxene.

The interlayering of the two varieties of amphibolite, their mineral composition, and the swirled phenocrysts suggest that they are metamorphosed basalt lava flows or perhaps concordant intrusives.

METARHYOLITE

Fine-grained metarhyolite crops out in four places between Forge Pond and Reservoir Pond to the northeast. Two of the exposures are on the southwest side of the amphibolite along Pequid Brook; the other two are along Forge Pond. 
The metarhyolite is medium dark and greenish gray where fresh and light olive gray where weathered. Some of the rock is thinly laminated. The metarhyolite on the ridge west of Pequid Brook and at the southwest corner of Forge Pond is intruded by apophyses of Dedham Granodiorite. The exposures near the outlet of Forge Pond contain aplite dikes 2 inches to 2 feet thick that are probably related to the Dedham Granodiorite and also numerous stringers of epidote $1 / 8^{-2}$ inches thick. Lenticular segregations of quartz, a few inches thick, are present in a few places. Shear fractures of small displacement are numerous.

The metarhyolite has a fine-grained granoblastic texture in which the mineral grains are anhedral and range mostly from 0.05 to $0.3 \mathrm{~mm}$ in greatest dimension. No porphyroblasts or relic phenocrysts were seen. The principal minerals are quartz (25-35 percent); untwinned plagioclase feldspar, probably albite (30-50 percent) ; clear untwinned potassium feldspar (10-25 percent); and green biotite (0-10 percent). The accessory minerals are magnetite, sphene, and apatite. The secondary minerals are chiefly sericite, chlorite, and epidote. The plagioclase feldspar is much altered to sericite and other secondary minerals; before alteration it may have been more calcic than the present albite. The potassium feldspar occurs as clear, unaltered, equidimensional grains that resemble quartz but have lower indices of refraction. The biotite is in disseminated dull green flakes, $0.05-$ $0.3 \mathrm{~mm}$ in greatest dimension, that show some preferred orientation. The biotite of the metarhyolite exposure at the outlet of Forge Pond has been completely altered to chlorite, and that on the ridge 1,100 feet southwest of Reservoir Pond has been partly altered. At the other two localities, the biotite is unaltered.

The fine-grained texture and the abundance of quartz and potassium feldspar indicate that the metarhyolite was formed by metamorphism of silicic volcanic rock. The laminations in several of the outcrops are considered to be relict flow banding, and the rock presumably was originally deposited as a sequence of rhyolite flows.

The close association and similar grade of metamorphism of the metarhyolite and the amphibolite indicate that the metarhyolite, like the amphibolite, is older than the Salem Gabbro-Diorite. The laminae and contacts in the outcrops southwest of Reservoir Pond strike northwest and dip steeply southwest. The contact between the metarhyolite and the amphibolite is well exposed for about 10 feet at the south end of the outcrop. It is sharp and conformable, and the metarhyolite overlies the amphibolite. 
The Green Lodge Formation of Late Cambrian age was named by Rhodes and Graves (1931, p. 364) from very limited exposures of quartzite and phyllite on the south side of present Route 128 in the northeastern part of the Norwood quadrangle. Rhodes and Graves describe the formation as consisting of "gray, crystalline quartzites interbeded with dark gray phyllite" and interpreted its thickness as not less than 1,000 feet. They assigned the unit a Late Cambrian age on the basis of several impressions of poorly preserved brachiopods. The quartzite was also observed by Loughlin (1911, footnote on p. 7, and fig. 2 on p. 26) and by Loughlin and Hechinger (1914, p. 61), who suggested that it might correlate with the "Coal Measures" of the Narragansett basin.

Light-gray quartzite of the Green Lodge Formation of Rhodes and Graves (1931) was exposed in 1961 in an area about 25 feet long and 15 feet wide, flush with the ground, just southwest of Interchange 59. Phyllite overlying the quartzite was temporarily exposed in an outcrop about 3 feet in diameter in a roadcut about 200 feet northwest of the quartzite exposure and in a house-basement excavation about 175 feet northwest of the quartzite exposure. Abundant fragments of phyllite were seen in the backfill of a ditch along the southwest side of the road for a distance of several hundred feet northwest of the exposure in the roadcut. These exposures imply that the Green Lodge Formation consists of quartzite of undetermined thickness overlain by dark-gray phyllite at least 500 feet thick.

The exposed quartzite is uniformly light gray and finely granular. It is cut by a few small white quartz veins that contain chlorite, as well as by numerous irregular limonite-stained cracks. Small flakes of muscovite are scattered through the rock. Bedding is not readily distinguishable but appears to strike about N. $70^{\circ} \mathrm{E}$. and to dip about $55^{\circ} \mathrm{NW}$. Neither contact of the quartzite is exposed and the thickness is unknown.

Most of the phyllite contains light-gray siltstone laminae and layers $1 / 16^{-1 / 2}$ inch in thickness. These laminae and layers are composed of quartz having small iron-stained pits which probably originally were filled with iron-bearing carbonate or pyrite. The fragments found in the ditch are dark-gray fine-grained phyllite.

The bedding and cleavage of the phyllite exposed in the house-basement excavation are parallel; they strike about N. $50^{\circ} \mathrm{E}$. and dip about $55^{\circ}$ N.W. At the exposure in the road, the cleavage strikes about N. $80^{\circ}$ E. and dips about $40^{\circ} \mathrm{NW}$.; bedding could not be recognized. 
PHYLIITE

Phyllite of unknown age is exposed at intervals for several hundred feet along the main line of the New York, New Haven, and Hartford Railroad a few hundred feet northeast of the Norwood-Walpole town line. Fragments on the small knobs south of Hawes Brook indicate that phyllite extends at least 200 feet east of the cut. This phyllite is somewhat more metamorphosed than the phyllite of the Green Lodge Formation of Rhodes and Graves (1931). The cleavage surfaces commonly show minute crinkles; in places, there are two directions of cleavage. The strike of the principal cleavage is nearly east-west and the dip is about $40^{\circ} \mathrm{N}$. S'mall decomposed limonite-stained porphyroblasts and a deformed bed of light-gray carbonate-rich rock about 1 foot thick occur in the phyllite. The phyllite may be part of the Green Lodge Formation but is 4 miles away, and exposures are inadequate for correlation.

\section{IGNEOUS ROCKS}

The igneous rocks of the Norwood quadrangle consist of a variety of intrusive and volcanic rocks that may range in age from Precambrian to Triassic. The Salem Gabbro-Diorite, the Newburyport Quartz Diorite, the Dedham Granodiorite, and the Westwood Granite are pre-Carboniferous. Whether the Sharon Syenite, its associated rocks, and the Mattapan Volcanic Complex are Carboniferous or preCarboniferous is not certain.

\section{SALEM GABBRO-DIORITE}

The Salem Gabbro-Diorite was named for Salem in Essex County, Mass., where it is widely distributed and typically developed (Clapp, 1910). Because of extensive intrusion and assimilation by the Dedham Granodiorite and the Westwood Granite, only small inclusions and roof pendants of the Salem Gabibro-Diorite remain in the Norwood quadrangle.

Both Emerson (1917, p. 178-181) and LaForge (1932, p. 23-25) described the Salem Gabbro-Diorite as a complex consisting of a variety of mafic rock types that grade into each other. Because of the sparseness of labradorite and augite west of the Norwood quadrangle, Dowse (1948, p. 30) called the rock Salem Diorite.

Two varieties of Salem Gabbro-Diorite have been distinguished in the Norwood quadrangle. One, a medium-grained variety, constitutes most of the mapped unit; the other, a coarse-grained pegmatitic variety, occurs as lenses within the medium-grained variety and has not been separately mapped. Both varieties are well exposed in the large roadcuts at Interchange $55 \mathrm{~B}$ on Route 128 near the north border of the quandrangle. 
The medium-grained variety is dark greenish gray and is characterized by an abundance of slender, unoriented hornblende crystals and tabular plagioclase feldspar crystals, $0.3-5 \mathrm{~mm}$ long. This variety consists of 55-75 percent albite or oligoclase and 10-35 percent hornblende; it also contains smaller amounts of orthclase-perthite, quartz, magnetite, pyrite, apatite, and sphene. The secondary minerals are chiefly chlorite, epidote, clinozoisite, and sericite. Some of the plagioclase is zoned; rims of albite or oligoclase enclose cores so altered as to be unidentifiable.

The pegmatitic Salem Gabbro-Diorite in the Norwood quadrangle, as shown by figure 1 , is characterized by numerous long, narrow, diversely oriented hornblende crystals $0.5-2.5$ inches long. White to pale-pink feldspar and quartz are the other principal constituents. This variety occurs in the medium-grained variety as irregular lenticular bodies, a few inches thick, erratically distributed in zones a few feet to a few tens of feet thick. Gradational boundaries, an increase in grain size toward the center, and a few miarolitic cavities indicate that these lenticular bodies are pegmatitic segregations.

The best exposures of the pegmatitic variety are in the roadcuts of Interchange 55B. Here the rock contains about 70 percent albite, 5 percent quartz, 10-15 percent hornblende, and smaller amounts of

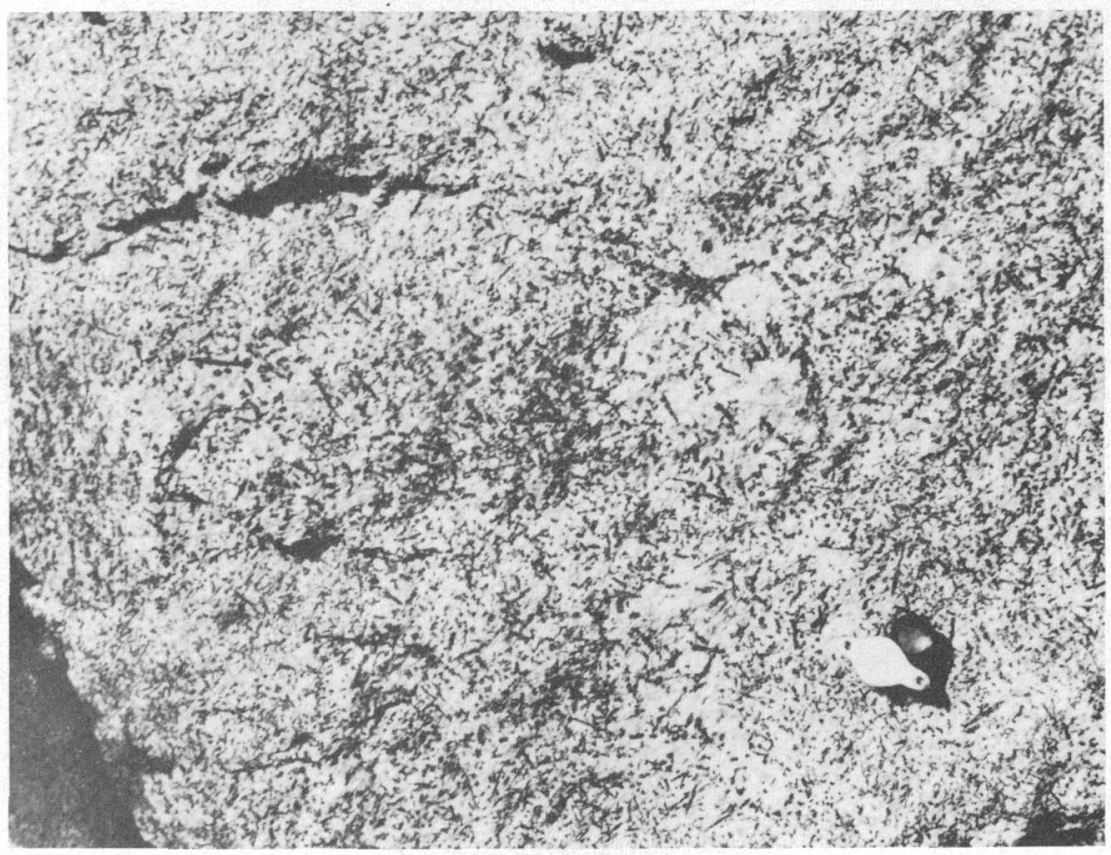

Figure 1.-Pegmatitic Salem Gabbro-Diorite, Long dark crystals are hornblende. Roadcut at Interchange $55 \mathrm{~B}$ on Route 128. 
perthite, micropegmatite, and apatite. The secondary minerals are chlorite, clinozoisite, epidote, and sericite. The albite is in tabular crystals, about 1-33 $\mathrm{mm}$ in greatest dimension, that are somewhat, altered to sericite and clinozoisite. Perthite rims some of the albite crystals. The hornblende is in dull green grains, the cores of which are altered to epidote and chlorite. Quartz and pink perthite are concentrated in places in grain aggregates readily visible to the unaided eye. This variety was the last part of the rock to be crystallized and probably owes its coarser texture and greater content of quartz and potassium feldspar to local segregations of residual liquids.

The medium-grained variety of Salem Gabbro-Diorite becomes lighter in color and contains more salic minerals in the vicinity of the pegmatitic variety, as can be seen in the roadcuts at Interchange 55B. The most nearly normal Salem Gabbro-Diorite here is composed of about 60 percent albite, 30-35 percent hornblende, and smaller amounts of perthite, pyrite, sphene, and apatite.

Where it grades into the pegmatitic variety, the medium-grained rock becomes progressively lighter in color, the grain size increases, the amount of hornblende decreases to about 15 percent and the amount of orthoclase and microperthite increases. Quartz appears and increases to about 15 percent, and a graphic intergrowth of quartz and potassium feldspar appears and increases to about 10 percent. The mineralogical changes show that potassium and silicon increase and that iron, magnesium, and calcium decrease. These changes were probably brought about by local differentiation during crystallization of the Salem Gabbro-Diorite.

The Salem Gabbro-Diorite in the Norwood quadrangle has been altered so that calcic plagioclase has been extensively saussuritized, and only albite and sodic oligoclase remain. Although this rock is not connected with the body at the type locality and has a somewhat different mineral composition than in the type locality, it has the occurrence and age relations of the Salem Gabbro-Diorite, and therefore, the same name is used.

In places the Salem Gabbro-Diorite has been altered at its contacts with the Dedham Granodiorite and the Westwood Granite. The chief effects of this alteration are a local increase in quartz and feldspar and a partial or complete transformation of hornblende to biotite. Because these changes are interpreted to be the result of contact metamorphism of the Salem Gabbro-Diorite, the rock types thus produced are not treated as separate varieties but are mapped as Salem GabbroDiorite. 


\section{NEWBURYPORT QUARTZ DIORITE}

Several bodies of diorite in the Norwood quadrangle are correlated with the Newburyport Quartz Diorite, named for its occurrence at Newburyport, Mass. (Emerson, 1917, p. 177-178). Although this rock seems to be gradational with the Salem Gabbro-Diorite in places, it occurs in individual bodies of sufficient size and distinctiveness to be treated as a separate rock unit rather than as a variety or facies of the Salem Gabbro-Diorite. The two largest bodies are each about 4,500-5,000 feet long and 2,000-2,500 feet wide. One of these is near the Canton-Sharon town line; the other is on the east side of Willett Pond. Other much smaller bodies are exposed in the roadcut at Interchange 55B; about 2,000 feet southeast of the Gay Street bridge over Purgatory Brook, and east of the intersection of Nahatan and Clapboardtree Streets in Westwood on Nahatan Street. The small outcrop in the northwestern corner of the quadrangle is part of a large body of quartz diorite that extends into the Newton quadrangle (LaForge, 1932, pl. 1).

The Newburyport Quartz Diorite of the Norwood quadrangle is a medium-to coarse-grained dark-greenish-gray rock characterized by nearly equidimensional poikilitic hornblende crystals whose sections appear round or square. The rock is somewhat variable in grain size but is noticeably massive and free of visible alteration and of shear fractures. A few small felsite dikes of the Mattapan Volcanic Complex and aplite dikes and epidote stringers cut the rock; apophyses of Dedham Granodiorite and Westwood Granite are scarce.

Hornblende crystals, ranging from 1 to $10 \mathrm{~mm}$ in diameter, constitute about 25 percent of the rock; they contain abundant inclusions of small feldspar crystals. Altered tabular plagioclase crystals form about 65-70 percent of the rock. The original composition of the feldspar is unknown because of the extensive alteration to clinozoisite, sericite, and albite, but it was probably calcic oligoclase or andesine. A small amount of perthite or orthoclase is present in some of the rock. Quartz is interstitial and usually does not exceed about 5 percent. Other common accessories are sphene, magnetite, pyrite, and apatite. Biotite, which appears to be an alteration product of hornblende, was seen in some thin sections.

Because of its low quartz content and the low-grade metamorphism, the Newburyport Quartz Diorite of the Norwood quadrangle is, strictly speaking, a metadiorite rather than a quartz diorite. The quartz content, however, in places approaches 10 percent, and the rock has the same general characteristics and age relations as the Newburyport Quartz Diorite elsewhere; therefore, the formation name is retained in the Norwood quadrangle. 
Data obtained in the Norwood quadrangle indicate that the Newburyport Quartz Diorite was intruded at about the same time as the Salem Gabbro-Diorite and before the Dedham Granodiorite. In the Nodwood quadrangle, the Dedham Granodiorite and the Westwood Granite intrude the Newburyport Quartz Diorite. The hybrid variety of the Westwood Granite was seen in sharp contact with the Newburyport Quartz Diorite in two places in the northwest corner of the quadrangle. These contacts are in a roadcut on the southeast side of the unnamed street crossing the Ohio Trail near the north border of the quadrangle. In both exposures the Westwood Granite decreases in grain size within $31 / 2$ feet of the contact. The chilled contacts, together with the inclusions of Newburyport Quartz Diorite in the Westwood Granite, prove that the granite is the younger. Fragments of the Newburyport Quartz Diorite also occur in the intrusion breccia of the Westwood Granite exposed in roadcuts on Route 128 at and a short distance north of the north boundary of the quadrangle.

A gradational relationship between the Newburyport Quartz Diorite and the Salem Gabbro-Diorite was noted in the Norwood quadrangle. This relationship is best seen in the excellent large exposures in the roadcut at Intersection 55B. Here the Newburyport Quartz Diorite appears to grade into the Salem Gabbro-Diorite in places through a distance of several tens of feet; in other places the gradation takes place within a few inches, suggesting an intrusive contact. Apparently the Salem Gabbro-Diorite and the Newburyport Quartz Diorite in the Norwood quadrangle, as elsewhere, are closely related in age.

\section{DEDHAM GRANODIORITE}

The Dedham Granodiorite, one of the most widespread rock units in eastern Massachusetts as well as in the Norwood quadrangle, is named from its occurrence in Dedham, Mass. (Emerson, 1917, p. 176). Several different closely related rock types have been included in this formation in the past (Emerson, 1917, p. 176-177; Clapp, 1921, p. 24, 45). The Dedham Granodiorite is the biotitic normal granite of Crosby (1905, p. 390), the biotite granite series of Loughlin (1911, p. 19), and the normal granite of Bascom (1912, p. 132). The normal granite described by Bascom (1912, p. 134) as occurring in the Stony Brook Reservation and adjacent areas not far north of the Norwood quadrangle was mapped with the Dedham Granodiorite by LaForge (1932, pl. 1).

The Westwood Granite, previously included in the Dedham Granodiorite, has been mapped and described separately. The Dedham Granodiorite thus restricted varies somewhat in grain size and composition, but the varieties are not readily distinguishable in the field. 
The normal Dedham Granodiorite in the Norwood quadrangle is a massive medium- to coarse-grained light-pinkish-gray rock characterized by a high content of quartz and a low content of ferromagnesian minerals. Pegmatites are scarce, but aplite dikes a fraction of an inch to a few inches wide are common.

Most of the Dedham Granodiorite as mapped in the Norwood quadrangle is granite and quartz monzonite rather than granodiorite. The granite and quartz monzonite are of similar appearance and grade into each other by a change in the relative amounts of potassium feldspar and plagioclase. They appear to be parts of the same intrusive and are not separately mappable. Part of the variation in composition is the result of the assimilation of Salem Gabbro-Diorite and other mafic rocks.

The monzonite is composed of 20-55 percent microperthite, 25-45 percent oligoclase, 20-35 percent quartz, and smaller amounts of chlorite probably derived from biotite. The common accessory minerals are magnetite, hematite, sphene, and apatite. The secondary minerals are chiefly chlorite, sericite, epidote, and carbonate minerals.

A sample of granite from outcrops a short distance east of the East Dedham business section contains about 25 percent quartz, 50 percent perthite, and 25 percent sodic oligoclase. Ferromagnesian minerals are scarce. A sample of Dedham Granodiorite collected by Dowse (1948, table 5) in the Norwood quadrangle from a roadcut on Route 128 , two-tenths of a mile northwest of the Washington Street (Route 1A) intersection, contained 26.1 percent quartz, 47.8 percent perthite, 24.8 percent oligoclase, and 1.3 percent chlorite. The Dedham Granodiorite in the Norwood quadrangle is virtually the same as that in the Medfield and Holliston quadrangles (Dowse, 1948).

Much of the Dedham Granodiorite is cut by small shear fractures, some of which are slickensided. In places the fractures contain thin veinlets of epidote and quartz. The rock adjacent to some of the fractures has been altered, through a zone several inches wide, to lightgreen sericite and minor amounts of chlorite, probably the pinite of Crosby (1889). Fractures and alteration products are particularly abundant in the vicinity of faults in the northern part of the quadrangle. The outcrops on both sides of the south pond on Mother Brook at East Dedham are unusually highly fractured and altered, especially those exposed on the southwest side when the pond is low. The outcrops along the Stony Brook fault, on the northwest side of the railroad in the northeast corner of the quadrangle and in the railroad-cut just north of Canton Junction, are highly fractured, granulated, and hydrothermally altered. The outcrops along Sprague Street in Readville Manor also are considerably fractured and altered. 
The outcrops in the southeastern corner of the quadrangle, on the other hand, are relatively free of shear fractures and hydrothermal alteration, as are most of the outcrops south of Sprague Street in the Greenlodge area. The large outcrop on the north side of Bailey Street, about 1,000 feet weşt of Pine Street, is comparatively unaltered and contains inclusions of Salem Gabbro-Diorite rimmed by a small amount of hybrid rock.

The age of the Dedham Granodiorite was considered early Paleozoic by LaForge (1932, p. 22) and Precambrian by Billings (1929, p. 102). More recently Dowse (1950) concluded that the Dedham Granodiorite is of Precambrian age because of the contact relations of granite with Lower Cambrian strata at Hoppin Hill near North Attleboro, Mass.

In the Norwood quadrangle the Dedham Granodiorite intrudes the Salem Gabbro-Diorite and is intruded in turn by the Westwood Granite, dikes of the Mattapan Volcanic Complex, and diabase dikes. Recently Ramo and Fairbairn (1963) published preliminary age data on four samples of the granitic rock that underlies the Cambrian sedimentary rocks at Hoppin Hill near North Attleboro, Mass., and four samples of the Dedham Granodiorite, as mapped by Emerson (1917), to the north. Rb-Sr whole rock analyses of the samples from Hoppin Hill gave individual apparent ages ranging from 469 to 535 million years. Three of the four samples of presumed Dedham Granodiorite are actually of Westwood Granite. The fourth is a coarsely porphyritic granitoid rock containing large pink potassium feldspar phenocrysts from North Abington. This rock, probably a phase of the Dedham Granodiorite, has an apparent age of 684 million years. Because of numerous mafic inclusions in the vicinity of the sample site, the rock may be somewhat contaminated. The previous age determinations of the Dedham Granodiorite in eastern Massachusetts by Webber, Hurley, and Fairbairn (1956, p. 580) are now doubtful (Hurley and others, 1960, p. 247).

\section{WESTWOOD GRANITE}

A distinctive granite of widespread occurrence in the northwestern part of the Norwood quadrangle is here named the Westwood Granite for exposures near the Westwood-Norwood town line. This granite also occurs in the Blue Hills quadrangle (Chute, 1940), the Brockton quadrangle (Chute, 1950), the Medfield quadrangle (Dowse, 1948, p. 45, type 1 of the Dedham Quartz Monzonite), and probably elsewhere in southeastern Massachusetts. The Westwood Granite belongs to the same magma series as the Dedham Granodiorite, the Salem Gabbro-Diorite, and the Newburyport Quartz Diorite.

Most of the Westwood Granite, like the Dedham Granodiorite, is a light-pinkish-gray even-grained massive rock rich in quartz and low 
in dark minerals. Usually it can be distinguished from the Dedham Granodiorite by its finer grain size. In a few places, however, the grain size is large enough for the rock to resemble the Dedham Granodiorite; in other places it is small enough for the rock to resemble phases of the Mattapan Volcanic Complex.

The Westwood Granite is divisible into four varieties. A common light-colored variety, considered typical of this unit, and a porphyritic variety have been mapped. A hybrid variety and a pink variety have also been found but were not mapped separately.

The common variety, which constitutes most of the Westwood Granite in the quadrangle, is a light-pinkish-gray fine- to mediumgrained rock (most grains are $0.2-2 \mathrm{~mm}$ in diameter). This principal variety is exposed in many outcrops on the northwest side of Washington Street in the northern part of Norwood. The area bounded by Washington Street on the southeast, Nahatan Street on the southwest, and the Westwood-Norwood town line on the north, is taken as the type locality.

The common variety is composed of $25-35$ percent quartz, 25-45 percent orthoclase or microperthite, $15-35$ percent albite or sodic oligoclase, and $0-5$ percent microcline. A small amount of biotite, mostly altered to chlorite, is usually present. The principal accessory minerals are magnetite, sphene, and apatite. The secondary minerals are sericite in moderate amounts, and chlorite and epidote in small amounts.

A sample of the common variety of the Westwood Granite was collected by Dowse (1948) in the Norwood quadrangle near Interchange 55A. The sample contained 29.2 percent quartz, 38.8 percent orthoclase, 27.7 percent albite-oligoclase (anorthite content 10 percent), 4.3 percent biotite, a trace of magnetite and apatite; sericite and epidote were alteration products.

Chayes (1952, p. 247) made modal analyses of eight samples of the Westwood Granite collected near the intersection of Routes 109 and 128. The analyses show that the mineral content is $28.3-33.6$ percent quartz, 36.9-45.2 percent potassium feldspar, 17.0-26.3 percent plagioclase, 0.4-1.8 percent biotite, 0-0.7 percent muscovite, $0.5-0.9$ percent opaque accessory minerals, and $1.8-6.2$ percent nonopaque accessory minerals.

The porphyritic Westwood Granite has white phenocrysts of sericitized albite and sodic oligoclase and pink phenocrysts of perthite in a fine-grained pink to lavender groundmass of quartz and feldspar. This porphyritic rock forms a body nearly 2 miles in length along East Street between Route 128 and Oakdale. Many boulders having fresh clean surfaces were seen in an abandoned gravel pit on the 
northeast side of Interchange 58 on Route 128 at the East Street intersection.

The porphyritic rock is similar in mineral composition to the common variety of the Westwood Granite; a distinctive feature is a micrographic intergrowth of quartz and perthite. This intergrowth surrounds the feldspar phenocrysts and forms a considerable part of the groundmass. The porphyritic variety has not been seen in contact with the other rocks of the quadrangle except pre-Triassic diabase dikes.

Locally, the common variety of Westwood Granite is porphyritic near contacts. The outcrop in the southeastern part of Shattuck Park on the west side of Norwood contains a body of porphyritic Westwood Granite, too small to map, in intrusive contact with Dedham Granodiorite. Another small body of porphyritic Westwood Granite is exposed about 1,000 feet west of the Pine Hill School. Some of the rock at this locality may be the same as the rhyolite porphyry that Bascom (1912, p. 137) described as peripheral to, and gradational with, the microgranite in the Newton quadrangle.

The pink variety of the Westwood Granite, formerly quarried for building stone, is exposed in the roadcuts at Interchange 55A. The color is caused by an unusual amount of fine red hematite disseminated through the rock. The hematite may have been produced by emanations from large diabase dikes nearby, as the amount diminishes away from the dikes. This pink variety of granite has the same texture and mineral composition as the common variety.

The hybrid variety was formed where the Westwood Granite assimilated mafic rock, particularly the Salem Gabbro-Diorite. This hybrid variety is greenish gray and is somewhat darker than the common variety, but the two varieties grade into each other. The hybrid variety is not uniform in composition. It is characterized by a higher content of biotite and, where most contaminated, contains hornblende probably as xenocrysts. It usually has a lower content of quartz than the common variety. Inclusions of Salem Gabbro-Diorite are abundant and in places form an intrusion breccia (fig. 2). This breccia is most extensive in the northwestern corner of the quadrangle and is well exposed at Cat Rock, about 800 feet north of Worthǐngton Pond, and on the hills 500-1,500 feet southwest of Storrow Pond.

Hybrid rock occurs to a lesser extent in other places where the Westwood Granite has intruded mafic rock. One of these is the northern part of the Westwood Granite west of Reservoir Pond in Canton. Here the rock is contaminated near the Salem Gabbro-Diorite adjacent on the west. The contaminated Westwood Granite contains about 5 percent hornblende and about 15 percent green biotite in small flakes 
that have partly replaced the hornblende. The other constituents are sodic plagioclase, microperthite, quartz, magnetite, and apatite. Chlorite, sericite, and epidote are the common alteration products. The contaminated rock grades into the normal granite, and its composition is not uniform.

A fine-grained aplitic rock containing few or no inclusions seems to intrude the hybrid variety southwest of Storrow Pond, but the cover of lichen on the rock surfaces obscures the relations. This rock somewhat resembles the Stony Brook Granite of Bell (1948). It may, however, be aplite which commonly intrudes the Westwood Granite, especially in the contact zones.

The Westwood Granite has formed an intrusion breccia along its margin in places, especially in the northwestern part of the quadrangle and in the Newton quadrangle to the north. This breccia, shown in figure 3 , is exposed in roadcuts a short distance west of the southeastbound lanes of Route 128, from a few hundred feet north of Grove Street to the north boundary of the quadrangle. It is also exposed in the outcrops along the southeastbound lanes of Route 128 at the north boundary of the quadrangle. The large roadcuts on the northwestbound lanes of Route 128, in the southern part of the Newton quad-

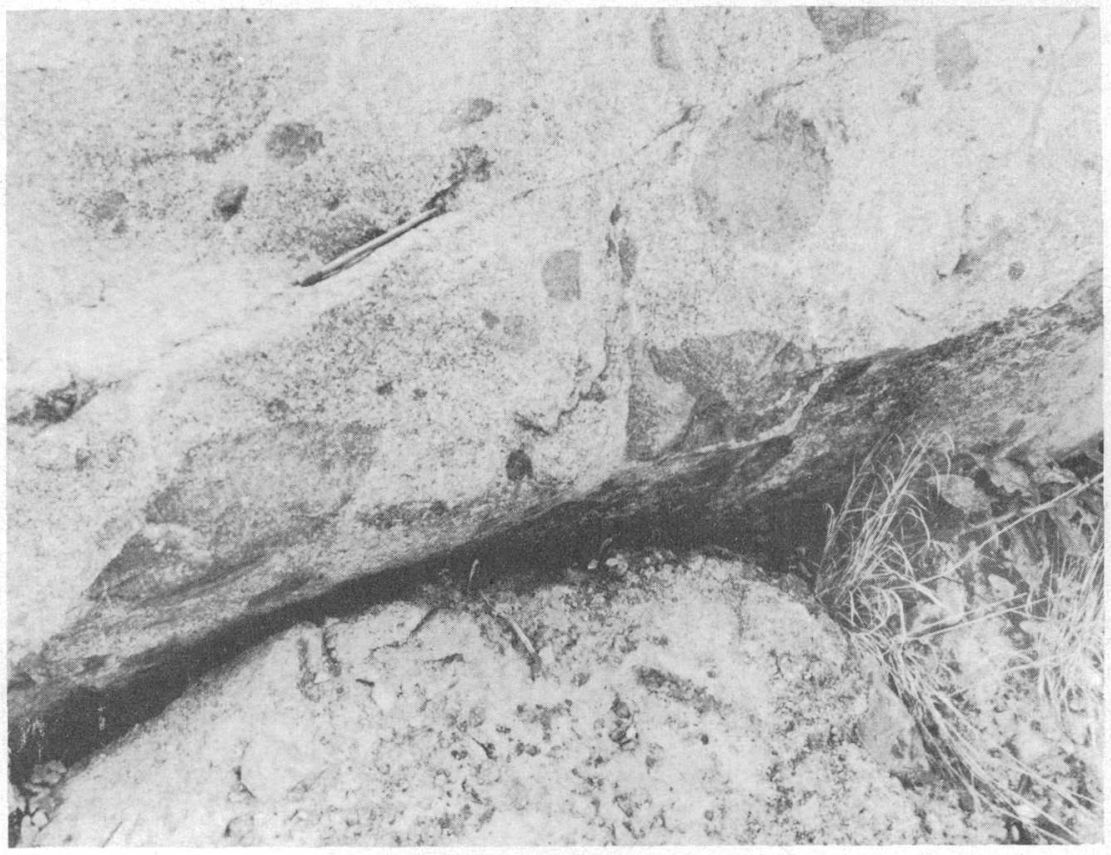

Figure 2.-Large glacial erratic of hybrid variety of Westwood Granite with inclusions of Salem Gabbro-Diorite. In gravel pit 1,000 feet southwest of Stevens Pond, Westwood. 


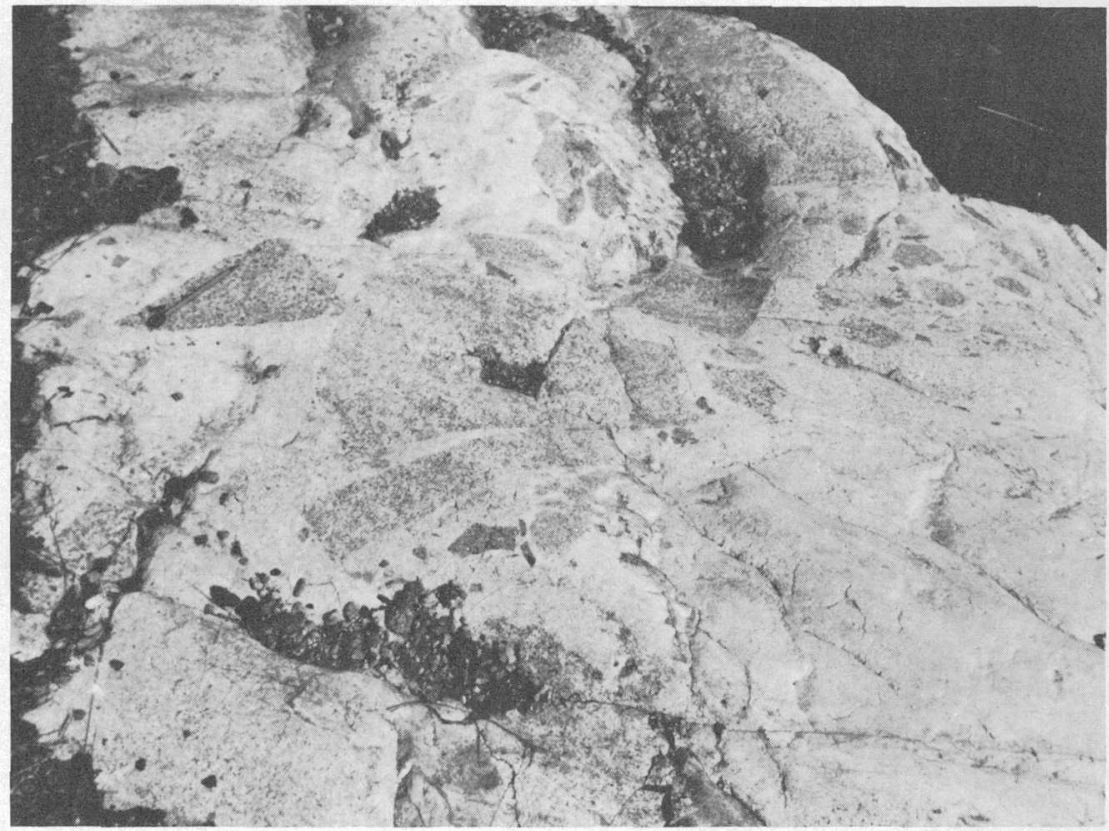

Figure 3.- Intrusion breccia formed by the Westwood Granite. Dark fragments are Newburyport Quartz Diorite. Roadeut about 1,000 feet south of the north boundary of the Norwood quadrangle on road near southwest side of Route 128.

rangle, have especially good exposures. One of these is about 800 feet, the other about 1,800 feet north of the Norwood quadrangle.

Fragments in the breccia range from a fraction of an inch to 3 feet or more in length. They consist of Salem Gabbro-Diorite, Newburyport Quartz Diorite, Dedham Granodiorite, and some fine-grained dark-green rock that may be altered basalt from the Marlboro Formation. That the fragments of the different rock types are intermixed indicates some transportation.

The matrix of the intrusion breccia is Westwood Granite variously contaminated by assimilation of mafic rock. Because of this contamination, the breccia varies in texture and composition within short distances and resembles the hybrid variety of the Westwood Granite. The distinction between the intrusion breccia and hybrid variety is made on the basis of volume of contained fragments. Where fragments exceed the matrix in volume, the rock is considered to be intrusion breccia; where the matrix exceeds the fragments, it is the hybrid variety.

The close relationship of the Westwood Granite to the Dedham Granodiorite is indicated by the areal distribution, but the Dedham Granodiorite consolidated before the granite was intruded, as is shown 
by the sharp contacts between the granodiorite and the granite and by the inclusions of Dedham Granodiorite in the granite.

In the past, because of similarity in color and close association, the Westwood Granite has been considered to be a phase of the Dedham Granodiorite. Dowse (1948, p. 45) divided the Dedham Granodiorite of the Medfield quadrangle into two types: type 1, equivalent to the Westwood Granite, and type 2, equivalent to the Dedham Granodiorite. She (p. 55) stated that "the plutonic breccia and hybrid rocks extend over large areas in Dover, Medfield, Norfolk, and Holliston and constitute at least 50 percent of the total outcrops of Dedham quartz monzonite and Salem diorite." The mineral analyses and descriptions of type 1 of the Dedham Granodiorite (called Dedham Quartz Monzonite by Dowse) indicate that it includes both the common variety and the hybrid variety of the Westwood Granite. The modes of 22 samples (Dowse, table 5) are 19.4-36.5 percent quartz, 19-39.5 percent orthoclase or perthite, $28.7-42.3$ percent albite or sodic oligoclase, 0-7 percent biotite, 0-16.7 percent hornblende, and 0-1 percent sphene. Six of the samples contain from a trace to 16.7 percent hornbleride. These samples are the most contaminated of the hybrid variety and have the least quartz (19.4-31.2 percent) and the most calcic plagioclase. Dowse stated (p. 46) that the hornblende is present only locally near the Salem Gabbro-Diorite inclusions and also ( $p$. 58) that the "contaminated quartz-monzonite [Westwood Granite] contains isolated altered plagioclase and hornblende grains as relics [xenocrysts] of diorite inclusions."

Bell (1948, p. 84-87) mapped and described exposures of a finegrained granite in the Stony Brook Reservation and adjacent areas, from 1 to $1 \frac{1}{2}$ miles north of the northeast corner of the Norwood quadrangle. He called this rock the Stony Brook variety of the Dedham Granodiorite because, like Crosby (1905, p. 393-394) and Bascom (1912, p. 134-140), he considered it to be a border phase of the Dedham Granodiorite and to grade into that rock. He described the Stony Brook variety as granodiorite grading into leucogranite near the normal Dedham Granodiorite. Exposures of the Stony Brook granite seen by the writer in the Stony Brook Reservation in the southeast corner of the Newton quadrangle are finer grained than the normal Westwood Granite and seem to be a different rock.

Bell $(1948$, p. 186) also described hybrid rocks in the Boston area produced by the injection of the Dedham Granodiorite into the Salem Gabbro-Diorite. He said (p. 189) : "Field evidence indicates that the granites and the more acid phases of the granodiorite, that is the magmas that were richest in potash feldspars were the most effective in producing hybrid rock types in the gabbro-diorite." Furthermore, 
he said that these hybrid rocks had been mapped by earlier geologists as Newburyport Quartz Diorite. The writer also observed that some of the hybrid variety of the Westwood Granite had been mapped with the Newburyport Quartz Diorite in the south west corner of the Newton quadrangle. Part, at least, of the hybrid rock in the Boston area, referred to by Bell, is probably equivalent to the hybrid variety of the Westwood Granite.

The Westwood Granite and the Dedham Granodiorite, having been grouped together in the past, were considered to be of the same age. As has been stated, the Westwood is now known to intrude the Dedham but probably belongs to the same period of igneous activity. Recently Ramo and Fairbairn (1963, p. 53) made preliminary Rb-Sr whole rock age determinations of the Dedham and of the Westwood Granite. A sample of the Westwood Granite from the west side of the intersection of Routes 109 and 128 in the northwest corner of the Norwood quadrangle has an apparent age of 562 million years. Another sample obtained from the north lanes of Route 128, in the Newton quadrangle, about 3,000 feet northwest of the first sample, has an apparent age of 548 million years. The first sample is the pink variety of the Westwood that has had its color changed by some hydrothermal alteration. The second sample has somewhat more chloritized biotite than the normal Westwood and is probably slightly contaminated by mafic rock.

Additional analytical work on these samples is in progress by Fairbairn. On the basis of the present results, Ramo and Fairbairn (1963, p. 53) are of the opinion that the Dedham Granodiorite, including the Westwood Granite, is of late Precambrian age.

\section{CARBONIFEROUS OR OIDER IGNEOUS ROCKS}

Carboniferous or older igneous rocks are restricted to the southern part of the quadrangle where they form a prominent chain of hills along the south side of the Norfolk basin from Canton Junction southwest for 8 miles, to and beyond the south border of the quadrangle. The Sharon Syenite is the most abundant unit of this group. Within it are small bodies of diorite, granite, and aplite, the larger of which are shown on the geologic map.

The age of these rocks is not closely determined because they have not been found in direct contact with the other rocks in the quadrangle, except pre-Triassic diabase dikes. A small inclusion of the pegmatitic variety of the Salem Gabbro-Diorite was found in the Sharon Syenite on the top of the hill 1,500 feet southwest of the junction of Neponset and Walpole Streets. This inclusion suggests that the syenite is younger than the Salem Gabbro-Diorite and also probably 
younger than the Newburyport Quartz Diorite, the Dedham Granodiorite, and the Westwood Granite.

In a few places in the Blue Hills quadrangle, small bodies of Sharon Syenite grade into rhomb-porphyry (locally called rhombenporphyry), which is probably a facies of the Sharon Syenite. This gradation indicates that the rhomb-porphyry and the syenite are the same or nearly the same age. Inclusions of the rhomb-porphyry in the Quincy Granite of Mississippian(?) age and in the Blue Hill Granite Porphyry indicate that the Sharon Syenite is older than these rocks.

\section{DIORITE}

A medium-grained dark-greenish-gray porphyritic diorite is exposed at intervals for 4,000 feet along a north-south belt in the Sharon Syenite north of Sharon. The best exposures are in the rock knobs southwest of Sharon Memorial Park. The diorite is composed of about 65 percent andesine, much altered to zoisite and sericite; about 30 percent augite, mostly altered to hornblende; 5 percent magnetite; and $0-2$ percent pyrrhotite or pyrite. The secondary minerals are sericite, epidote, zoisite, and chlorite. Some of the andesine occurs as irregularly distributed white tabular phenocrysts as much as 3 inches long and $1 / 2$ inch wide, but most of the phenocrysts are from $1 / 4$ to $3 / 4$ inch long. The feldspar grains of the matrix range from 1 to $31 / 2 \mathrm{~mm}$ in length. The augite occurs as grains $2-5 \mathrm{~mm}$ long that have polysynthetic twinning and that are partly altered to hornblende (uralite). Most of the chlorite is associated with the feldspar and magnetite; very little was formed by alteration of augite and hornblende.

Aplite dikes a fraction of an inch to a few inches thick intrude the diorite. These dikes are composed of white feldspar and a small amount of fine-grained ferromagnesian mineral and are probably genetically related to the diorite. A pegmatite dike 4-5 inches thick composed of coarse plagioclase and pyroxene crystals and considerable magnetite was seen in the northernmost exposure of the diorite. The gradational boundaries and the similarity of the minerals of the pegmatite and the diorite indicate that the pegmatite was derived from the diorite.

In places the diorite contains inclusions a few inches to a few tens of feet in diameter that are rich in coarse white plagioclase. These inclusions are very similar mineralogically to the diorite and may be early segregations of the feldspar phenocrysts broken up by flow.

A dike of Sharon Syenite 5-10 feet wide cuts the diorite at the top of the hill west of Chestnut Tree Cemetery. It has sharp contacts and contains inclusions of the diorite. 


\section{SHARON SYENITE}

The Sharon Syenite is a medium-grained granitoid rock composed of 80-85 percent perthitic orthoclase in anhedral grains $3-6 \mathrm{~mm}$ in longest dimension; in addition, it contains a small amount of microcline-perthrite, 1-5 percent oligoclase, $0-3$ percent quartz, and 4-5 percent hornblende. The feldspars are partly altered to sericite, clay minerals, epidote, and chlorite; the hornblende is partly altered to chlorite. In places the feldspar grains are crushed along thin shear zones; this crushing gives them a cataclastic texture. Some of the syenite exposed on the southeastern side of Canton Street, south of Sharon Memorial Park Cemetery, is finer textured than the rest, possibly from the crushing of the feldspar grains.

The syenite is usually more weathered and stained with limonite along fractures near the surface than are most of the other igneous rocks of the quadrangle, and this fact makes it difficult to obtain fresh specimens from natural outcrops. The abnormally deep weathering and staining probably is due, at least in part, to disseminated finegrained pyrite. This mineral was seen in fresh exposures of the rhomb-porphyry in the Blue Hills quadrangle.

\section{FINE-GRAINED GRANITE}

Fine-grained granite occurs as small irregular bodies and dikes in the Sharon Syenite. Only the two largest bodies on the prominent hills separated by Norwood Street, about a mile northwest of Sharon, are shown on plate 1.

This granite is finer grained than the Sharon Syenite. 'The quartz grains range from 0.3 to $1.3 \mathrm{~mm}$ in greatest dimension, and the perthite grains from 0.5 to $5.5 \mathrm{~mm}$, most of them being more than $1 \mathrm{~mm}$. The granite is medium gray on fresh surfaces and light brownish gray to brown on weathered surfaces.

The granite is composed of $25-30$ percent quartz, 55-65 percent perthite, 1-2 percent oligoclase, a small amount of biotite, about 5 percent chlorite, mostly as an alteration of biotite, and 3-5 percent secondary carbonate minerals. Magnetite, apatite, and sphene are present in small amounts.

An inclusion of Sharon Syenite seen in the granite indicates that the granite is the younger and has intruded the syenite. Because of the close spatial association of the granite and the syenite and their similarity in color and mineralogy, they were probably derived from the same magma.

\section{APLITE}

The aplite associated with the Sharon Syenite occurs as small irregular intrusive bodies and dikes. The largest body is in the south- 
central part of the quadrangle on the south side of Edge Hill Road.

The aplite is light gray and has a fine-grained sugary texture. The quartz grains range from 0.1 to $1.1 \mathrm{~mm}$ and the feldspar grains from 0.2 to $1.3 \mathrm{~mm}$, averaging about $0.4-0.5 \mathrm{~mm}$ in longest dimension.

The aplite is composed of about 35 percent quartz, 35-40 percent oligoclase, 20-25 percent microcline or microperthite, a few percent of green biotite partly altered to chlorite, and a small amount of epidote and leucoxene. In some specimens the plagioclase feldspar is completely altered to sericite and the species could not be identified.

\section{DEVONIAN OR CARBONIFEROUS ROCKS}

\section{IGNEOUS ROCKS}

\section{MATTAPAN VOLCANIC COMPLEX}

Erosional remnants of the Mattapan Volcanic Complex are widespread in the northern and central parts of the Norwood quadrangle, but none have been found within or south of the Norfolk basin. The largest remnant covers an area of about $21 / 2$ square miles in the northwestern part of the quadrangle and extends westward into the Medfield quadrangle. This remnant is only 1.3 miles south of a large area of volcanic rocks in the southwest corner of the Newton quadrangle.

The Mattapan Volcanic Complex in the Norwood quadrangle consists of felsite flows, pyroclastic rocks, small stocklike intrusives, and dikes. Gray felsite containing small inconspicuous phenocrysts of feldspar is widespread. Porphyritic sodic rhyolite that weathers pink occurs in three areas large enough to be shown on plate 1 . The pyroclastic rocks are exposed in several areas within the main body of the volcanic complex and in an isolated area east of Fox Hill. Other smaller exposures were found in the northeast corner of the quadrangle in Readville Manor, East Dedham, Readville, and Hyde Park. No andesite or basalt flows and dikes, such as occur in the Boston area (LaForge, 1932, p. 31, 34), were found.

The flows and pyroclastic rocks were deposited on a surface of moderate relief. The exposures range in altitude from about 50 to 300 feet, and small prevolcanic hills of Dedham Granodiorite project through the volcanic rocks in three places in the northwest part of the quadrangle.

The Mattapan Volcanic Complex in the Medfield quadrangle is more varied than in the Norwood area. Dowse $(1948$, p. 64) stated that "the volcanics consist of flows, tuffs, and breccias, which are dominantly siliceous in composition but in part are andesitic and basaltic. The associated rocks include a very small amount of conglomerate, sandstone, and argillite. Also associated with the vol- 
canics in the eastern part of Dover are small intrusions of granite porphyry, quartz diorite and various dikes."

Bascom $(1912$, p. 141, 159) pointed out that the Mattapan Volcanic Complex in the Neponset River valley area north and northeast of the Norwood quadrangle is composed chiefly of sodic rhyolite in which albite feldspar is an abundant constituent. The volcanic rocks in the Norwood quadrangle also contain considerable albite.

Concerning the compositions of the rhyolites of the Medfield quadrangle, Dowse $(1948$, p. 77$)$ said,

The new analyses are very similar to one another in that they have slightly more soda than potash, and soda considerably in excess of lime. However, they differ from the old analyses, that of an unusually soda-rich rock described by Florence Bascom (1900) as apo-soda-rhyolite. Its norm contained a large amount of acmite because of the high soda content and a smaller content of alumina than is common in rhyolite. None of the modes of the Mattapan volcanics and associated rocks in the Medfield quadrangle indicates rocks as alkaline as the volcanics in the Neponset valley or the Quincy granite. The soda content of the analyses 9,10 , and 11 is essentially the same as that of analysis 13 of the Quincy granite, but the norms of the first three show that they contain enough alumina to combine with all the soda to make albite whereas the Quincy granite does not contain sufficient alumina and its mode commonly includes some riebeckite and aegirine.

The Mattapan volcanics differ from the Dedham quartz monzonite and the Milford granite by having more soda and slightly less potash. Three of the four analyses of the rolcanics have less silica than the Milford granite and Dedham quartz monzonite.

The Mattapan Volcanic Complex was considered by LaForge (1932, p. 35) to be an early effusive phase of the Quincy Granite intrusive because of the chemical similarities. The Blue Hill Granite Porphyry, and also apparently the Quincy, were intruded close enough to the surface to penetrate into the volcanic rocks. Small inclusions of porphyritic felsite, closely resembling the gray rhyolite of the Mattapan Volcanic Complex, occur in the Blue Hill Granite Porphyry at the east edge of the Norwood quadrangle and in the Blue Hills quadrangle to the east.

The rocks of the Mattapan Volcanic Complex have been considered Devonion or Carboniferous (LaForge, 1932, p. 28-29). In the Norwood quadrangle, they are known to be younger than the Dedham Granodiorite and older than the Blue Hill Granite Porphyry. Using the whole-rock Rb-Sr method, Bottino (1963, p. 65) obtained an apparent age of $248 \pm 10$ million years for the "aporhyolite" of the northern part of the Blue Hills quadrangle, probably a part of the Mattapan Volcanic Complex. Field studies indicate, however, that the "aporhyolite" in the eastern part of the Blue Hills quadrangle is intruded by the Quincy. 


\section{GRAY FELLSITES}

The gray felsites are predominantly medium dark gray and weather lighter gray or purplish gray. Flow banding is distinguishable in some of the felsite, but most of the rock is massive. Because individual flows and different varieties of the gray felsites were not sufficiently distinguishable in the field, they were mapped together.

Small remnants of felsite, a few inches to a few feet long, that probably belong to the Mattapan Volcanic Complex are fairly common in exposures of the Dedham Granodiorite and the Westwood Granite in the north half of the Norwood quadrangle. These exposures show that the Mattapan Volcanic Complex was formerly much more extensive than at present. Many of these remnants appear to be inclusions of older volcanics, but their sharp contacts, the lack of metamorphism, the small apophyses that extend from them into the adjacent rock, and the scattered inclusions of the adjacent rock, show that they are remnants of dikes or flows that are younger than the Dedham Granodiorite and Westwood Granite.

Although too small to show on the map, these remnants are exceptionally well exposed in several of the large outcrops of Dedham Granodiorite 500 feet southwest of Sprague Street, a few hundred feet northwest of the standpipe in the Greenlodge section of Dedham. Here they are clearly parts of flows or dikes of low dip that are probably a part of the Mattapan Volcanic Complex and not inclusions of older volcanics.

Typically the gray felsite contains about 5 percent albite phenocrysts, as much as $1.5 \mathrm{~mm}$ in greatest dimension, in a fine-grained matrix composed of anhedral grains of quartz and feldspar less than $0.5 \mathrm{~mm}$ in diameter. The feldspar of the matrix is untwinned and has indices of refraction distinctly lower than quartz. The accessory minerals are magnetite, muscovite, and apatite; the secondary minerals are chiefly chlorite, epidote, and leucoxene. Some of the felsite on Fox Hill contains small angular fragments of quartz, feldspar, and country rock.

Light-gray bleached felsite, having much limonite stain on fractures, was uncovered in excavating sand and gravel at the foot of the hillside on the west side of the Neponset River valley, about 3,500 feet southwest of Interchange 59. The limonite-stained rock contains many quartz veinlets $1 / 8-2$ inches wide having partly altered pyrite along the walls and disseminated in the rock. A small amount of sphalerite and galena was found in two of the veinlets. The fractured and mineralized condition of this felsite was probably due to its proximity to the Stony Brook fault. 
PINK PORPHYRITIC RHYOLITE

The pink porphyritic rhyolite is identified by its color on weathered surfaces and by its abundant phenocrysts. The contact relations of this rhyolite and the Westwood Granite half a mile northwest of Islington indicate that the rhyolite intrudes the granite. The porphyry exposed in the ridge on the north side of Hartford Street, 1,800 feet east of the west edge of the quadrangle, however, has such a fine-grained matrix that it may be extrusive. At this locality the rhyolite contains about 25 percent quartz and albite phenocrysts, $0.5-1.5 \mathrm{~mm}$ in greatest dimension. The matrix consists of very fine-grained quartz and untwinned feldspar that may have resulted from devitrification. Magnetite, apatite, sericite, epidote, keucoxene, and clay minerals are present in small amounts.

\section{PYROCLASTIC ROCKS}

The pyroclastic rocks are composed chiefly of fragments of gray and pink felsite but also contain fragments of Dedham Granodiorite and Westwood Granite in places. The fragments are mostly angular to subangular and usually are less than 8 inches long The coarsest fragmental material was found on the crest of the hill about 3,000 feet east of Fox Hill, where some of the fragments, many of which are Dedham Granodiorite, are as much as 4 feet long. Bedding is not identifiable in most places. Some of the fragmental volcanic rock shows eutaxitic structure similar to that ascribed to ash-flow tuffs by Ross and Smith (1961, fig. 13). Volcanic breccia containing abundant small fragments of felsite is exposed in several places in the southern part of Readville Manor, Dedham.

The pyroclastic rocks are most extensive northwest of the center of Westwood. Coarse breccia having abundant Mattapan felsite and Dedham Granodiorite fragments is well exposed on the northwest side of High Street 2,400 feet southwest of the intersection with Nahanton Street. A few thin sandy layers here show that the bedding strikes $\mathrm{N} .35^{\circ} \mathrm{E}$. and dips about $65^{\circ} \mathrm{NW}$. Graded bedding indicates that these beds may be overturned. A short distance to the west, on the hill called Satan's Kingdom, the beds strike N. $70^{\circ}$ E. and dip $75^{\circ} \mathrm{NW}$.

Fragmental volcanic rocks, chiefly tuff breccia, are exposed at the west end of the bridge orer the railroad 1,600 feet southwest of the northeast corner of the quadrangle. Most of the fragments are felsite and are less than 1 inch in diameter; a few are as much as 4 inches in diameter. The rock is much fractured and altered because of the proximity of the Stony Brook fault, and no bedding was seen. Similar volcanic breccia is exposed in a small outcrop on the east side of Hyde Park Avenue, 2,800 feet to the south. 
Volcanic breccia that, except for the angularity of its fragments, might be confused with the Roxbury Conglomerate is exposed near the side of a house about 550 feet south of the north edge of the quadrangle and 325 feet west of the Boston City boundary. The exposure is near the bottom contact of the Roxbury Conglomerate that crops out on the ridge to the east. The breccia contains many angular fragments of pink and red felsite and has small fragments of Dedham Granodiorite in the matrix.

\section{FELSITE DIKES}

Felsite dikes are common in the northern part of the Norwood quadrangle, but none are of sufficient size to be shown on plate 1 . These dikes cut all the bedrock formations except the Roxbury Conglomerate, the Carboniferous and Triassic diabase dikes, and the Norfolk basin sedimentary rocks. None of these dikes were seen in the pink porphyritic rhyolite, which may be younger than most or all of the dikes. The best exposures are in the roadcuts along Route 128 northwest of Route $1 \mathrm{~A}$.

The felsite dikes are various shades of purple, red, green, and gray, depending on the amount of hematite, magnetite, and green alteration minerals. Some of the dikes show flow banding, particularly near the contacts, and some contain small feldspar phenocrysts. Most are probably rhyolite.

A rhyolite dike 17 feet wide is exposed in the roadcut on the northwestbound lanes of Route 128, about halfway between Routes 1 and 109. The dike contains $15-20$ percent albite phenocrysts ranging from 0.3 to $3 \mathrm{~mm}$ in length and has some rectangular patches of chlorite and epidote that were probably phenocrysts of hornblende or biotite. The matrix has $20-25$ percent quartz, and the remainder is albite and potassium feldspar and a small amount of magnetite, apatite, epidote, and chlnrite. This rock weathers light pinkish gray. Another rhyolite dike, of similar composition, about 20 feet wide, is exposed on the northeast side of the northwestbound lanes of Route 128 , about 800 feet northwest of Route $1 \mathrm{~A}$.

\section{BLUE HILL GRANITE PORPHYRY}

The Blue Hill Granite Porphyry is estimated to extend about half a mile into the Norwood quadrangle from the Blue Hills quadrangle on the east. The best exposures are at the east edge of the quadrangle, southeast of Green Street. The porphyry here is medium gray and weathers light gray or pinkish gray. Phenocrysts of perthite, quartz, and riebeckite, most of which are anhedral, constitute $60-70$ percent of the rock and are set in a matrix whose grains are not readily discernible except in thin section. The perthite phenocrysts range from 
about 1 to $8 \mathrm{~mm}$ in greatest dimension, and the quartz phenocrysts from 1 to $3 \mathrm{~mm}$. The riebeckite phenocrysts are poikilitic, range from 0.3 to $2 \mathrm{~mm}$ in length, and make up 5-10 percent of the rock. The matrix is composed of grains of anhedral quartz and untwinned feldspar, mostly from 0.02 to $0.1 \mathrm{~mm}$ in diameter, enclosing many microscopic needle-shaped crystals of riebeckite.

Accessory and secondary minerals are notably scarce in the Blue Hill Granite Porphyry as compared with the other pre-Triassic igneous rocks of the quadrangle. The feldspar is dusty because of slight alteration to clay minerals.

For many years the Blue Hill Granite Porphyry and the Quincy Granite have been considered vitually contemporaneous, on the basis of the belief that the Blue Hill Granite Porphyry is a chilled marginal phase of the Quincy Granite. The writer recently, however, has found evidence in the Blue Hills quadrangle that the Blue Hill Granite Porphyry is a separate intrusion younger than the Quincy Granite. Irregular small bodies of Quincy Granite in the porphyry, previously interpreted to be dikes, are probably xenoliths. Using the $\mathrm{Rb}-\mathrm{Sr}$ whole rock method, Bottino, Pinson, Fairbairn and Hurley (1963) and Bottino (1963, p. 65) obtained an apparent age of $245 \pm$ million years for the Blue Hill Granite Porphyry and $325 \pm 15$ million years for the Quincy Granite in the Blue Hills quadrangle.

\section{SEDIMENTARY ROCKS}

\section{ROXBURY CONGLOMERATE}

The Roxbury Conglomerate is mapped as a narrow erosional remnant on the downthrown side of a northeasterly trending reverse(?) fault in the northeastern corner of the Norwood quadrangle. The rocks in this remnant include conglomerate, which is well exposed, tillite, which is doubtfully exposed, and slate, which is not exposed but which is represented by numerous fragments scattered over the surface of the ground. The formation is considered to be of nonmarine origin.

According to Emerson (1917, p. 56) the Roxbury Conglomerate is divisible into three members: "the Brookline conglomerate at the base, the Dorchester slate in the middle, and the Squantum tillite at the top." LaForge (1932, p. 39) included the Roxbury Conglomerate as the lowest formation in the Boston Bay Group. He indicated that information gained from excavations showed that the threefold division proposed by Emerson did not persist throughout the area occupied by the formation. Although he did not map the units separately, LaForge retained the names for convenience in describing the formation. The threefold division of the formation apparently is valid in 
the Norwood quadrangle, but because of poor exposures, no attempt was made to map the members separately.

The Brookline Conglomerate Member has resisted erosion better than other parts of the formation and forms a prominent ridge along the northwest side of Fairview Cemetery. This ridge, which in the Norwood quadrangle is about half a mile long, terminates toward the southwest at Mother Brook. Southwest of Mother Brook the conglomerate is exposed only in the railroad-cut and has no topographic expression.

The conglomerate along the crest of the ridge northeast of Mother Brook is well exposed in large glaciated outcrops. It contains abundant cobbles and a few small boulders as much as 12 inches across. Finer conglomerate, containing thin interbedded lenticular layers of arkosic sandstone, is exposed on the lower slopes of both sides of the ridge.

The pebbles, cobbles, and boulders of the conglomerate are composed of about 85 percent porphyritic felsite in a variety of colors, 5-10 percent Dedham Granodiorite and Westwood Granite, and 5 percent miscellaneous rock types. Some white quartz pebbles are present, but quartzite is scarce. The matrix of the conglomerate consists mostly of clear quartz grains, feldspar grains, and rock fragments that range from coarse sand to granule size. In most places, the pebbles, cobbles, and boulders of the coarse conglomerate are so closely packed that they touch.

Most of the pebbles, cobbles, and boulders are oval and fairly well rounded; some are discoid to tabular. Bedding is obscure in most places in the conglomerate. A few thin coarse arkosic sand lenses show that the beds strike N. $50^{\circ}$ E. and $\operatorname{dip} 70^{\circ}-75^{\circ} \mathrm{SE}$. Crossbedding, observed in a few places in the sandstone lenses, dips northeastward. The high percentage of felsite pebbles and cobbles, probably derived from the Mattapan Volcanic Complex, shows that the bedrock in the source area was dominantly volcanic.

The Dorchester Slate Member of the Roxbury Conglomerate may be present on the southeast side of the conglomerate ridge. Its presence is suggested by fragments of purplish-gray siltstone and silty slate on the ground moraine along the south west side of the park at the north edge of the quadrangle. The fragments are scattered over the surface for several hundred feet southeast of the main entrance to the park. These fragments resemble some of the rock in the Dorchester Slate Member of the Boston area, described by LaForge (1932, p. 40).

The Squantum Tillite Member of the Roxbury Conglomerate also may be present in the park on the southeastern side of the Dorchester 
Slate area. Blocks of rock that resemble the Squantum are scattered over a low northeast-trending ridge near the center of the park. Two or three small areas of the tillite, one about 10 feet across, may be outcrops, and they suggest that the tillite underlies the ridge. This ridge is parallel to the conglomerate ridge, and if the beds dip southeast throughout the area, they are in the proper stratigraphic position for the tillite.

The tillite here is composed of an unsorted mixture of stones of all sizes as much as 12 inches across embedded in a silty matrix which weathers very light gray. Most of the stones in the tillite are lightyellowish-gray quartzite. Light-green quartzite, brown quartzite, granite, porphyritic felsite, and nonporphyritic flow-banded felsite are present in smaller amounts. The rock resembles till in the lack of sorting and stratification and in the angularity of most of the stones; also some of the stones have flat sides that resemble soled surfaces. Although this member has generally been considered a tillite, Dott (1961) recently interpreted it as a subaqueous slide unrelated to glaciation.

The age of the Roxbury Conglomerate, according to LaForge (1932, p. 38-39), is either Devonian or Carboniferous. Although a few plant fossils have been found in it, they are not definitive to date the formation more precisely. One possibly significant feature is the absence of pebbles and cobbles of the Blue Hill Granite Porphyry in the Roxbury Conglomerate and their presence in the base of the Pondville Conglomerate in the Norfolk basin. This absence of pebbles and cobbles may indicate that the Roxbury Conglomerate is older than the Pondville Conglomerate, but more likely is due to causes other than age difference.

\section{CARBONIFEROUS ROCKS}

The sedimentary rocks of Carboniferous age exposed in the Norwood quadrangle consist of the Pondville Conglomerate and Wamsutta Formation, of Pennsylvanian age, in the Norfolk basin in the southern part of the quadrangle. They are clastic nonmarine sedimentary rocks that contain a few plant fossils in places. New, exceptionally good exposures of the Pondville Conglomerate and the Wamsutta Formation can be seen in roadcuts along Route 128 in the Blue Hills quadrangle.

\section{PENNSYLVANIAN SEDIMENTARY ROCKS}

PONDVILLE CONGLOMERATE

The Pondville Conglomerate of Pennsylvanian age (Quinn and Oliver, 1962, p. 61) is divisible into two members in the Norwood 
quadrangle. The lower member consists of cobble and boulder conglomerate; the upper member consists of gray coarse sandstone, gray granule conglomerate, and pebble conglomerate.

The name Pondville Group was used by Woodworth (in Shaler and others, 1899, p. 134-141) to include basal arkose beds, and "suprabasal" conglomerates underlying the Wamsutta Formation and overlying pre-Carboniferous granite. Emerson $(1917$, p. 54) redefined the unit as the Pondville Conglomerate.

The two members of the Pondville Conglomerate can be traced along both sides of the Norfolk basin in the southern part of the quadrangle. Along the northern edge of the basin, the lower member apparently terminates at the Stony Brook fault and is absent to the west. The upper member continues about 3 miles farther west to another northeast-trending fault. Along the southern edge of the basin, the lower member seems to terminate at the Stony Brook fault and is absent east of the fault. These apparent terminations are interpreted by the author to be the result of thrust faulting, older rocks having been thrust over the Pondville Conglomerate from the north and south. (See pl. 1, sections $A-A^{\prime}, B-B^{\prime}$, and $C-C^{\prime}$.)

The lower member of the Pondville Conglomerate is $1,000-1,700$ feet thick in the Norwood quadrangle. It is mostly cobble conglomerate which, where coarsest, contains numerous cobbles $6-10$ inches across and a few small boulders 10-18 inches across. The very coarse boulder conglomerate at the base of the Pondville in the Blue Hills quadrangle does not extend as far west as the Norwood quadrangle.

The upper member of the Pondville Conglomerate is about 600 feet thick near the east edge of the quadrangle but thickens westward to 1,000-1,500 feet near the east side of the Neponset River; it maintains approximately this thickness southwestward to the fault in the scuthern part of Norwood. This member consists of gray sandstone and granule and pebble conglomerate. The lower member grades upward into the upper member through an interval of 25-100 feet. The basal arkose described by Woodworth (in Shaler and others, 1899, p. 135) was not found.

The pebbles, cobbles, and boulders of the Pondville Conglomerate are composed of many different types of rock, of which quartzite, felsite porphyry, and granite predominate. Pebbles and cobbles of Blue Hill Granite Porphyry occur in the lower part of the formation in the eastern part of the quadrangle. Plant fossils, particularly Calamites and Sigillaria were found by Woodworth (1894) in the upper member in the railroad cut four-fifths of a mile north of Canton Junction. The writer also found several impressions of Calamites at 
this locality. These plant fossils indicate that the Pondville is Carboniferous, but they are too poorly preserved to be used for definite dating.

\section{WAMSUTTA FORMATION}

The Wamsutta Formation of Pennsylvanian age (Hurley and others, 1960, p. 247) consists predominantly of fine-grained red sandstone and considerable interbedded red shale; it also contains some gray granule and pebble conglomerate. A distinctive purple shale a few tens of feet thick, interbedded with green shale and sandstone, is exposed on the floor of the large gravel pit on the southwest side of Neponset Street and in the roadcut on the northeast side of the street near the Neponset River. (See pl. 1.) Numerous small light-gray lenses of carbonate rock in red shale are exposed in three zones 1-8 feet thick in the railroad-cut about 11/2 miles north of Canton Junction. These lenses may be sheared and elongated carbonate nodules or concretions.

The common fine-grained red sandstone is composed of fairly well sorted subangular to subrounded quartz grains $0.05-0.3 \mathrm{~mm}$ in diameter. Small quartz grains form part of the matrix. Flakes of muscovite and grains of a carbonate mineral are disseminated unevenly through the sandstone. Other minor constituents are sphene, epidote, leucoxene, and hematite. The hematite coats the quartz grains and occurs in patches in the matrix.

Bedding is obscure in many of the outcrops of the sandstone, but thin laminae usually can be seen upon close examination. Crossbedding is common, and ripple marks and mud cracks are present in a few places. Crossbedded red sandstone is well exposed on the two hills between the Neponset River and the New York, New Haven, and Hartford Railroad in the east-central part of the quadrangle. Here the prevailing direction of dip of the crossbedding is southwest. Most of the red sandstone beds of the easternmost of the two hills range in thickness from about 3 inches to 2 feet. Pebbles occur scattered through some of the sandstone beds; a few of these are red shale eroded from underlying shale beds. Scour and fill structures are commonly associated with the beds of conglomerate.

A railroad-cut near Canton Junction exposes an unusually varied sequence of beds which strike about N. $65^{\circ}-70^{\circ}$ E. and dip steeply northwest. A few faults, probably small ones, cut the section nearly parallel to the beds. 
Section in Wamsutta Formation, in railroad cut $11 / 2$ miles north of Canton Junction

Thickness

(feet)

Chiefly pebble conglomerate, gray, and red sandstone; some shale 90

Vertical fault.

Chiefly sandstone, red with some shale and pebble conglomerate 60

Shale, slaty, greenish.

Sandstone, greenish-gray

Shale, slaty, green, crushed._. 3

Granule and small pebble conglomerate, gray 10

Sandstone, red : some thin shale partings

Shale, red; 40-50 percent small irregular carbonate lenses. Carbonate resembles limestone and weathers light gray

Sandstone, red._. 10

Shale, slaty, red. Bottom 7-8 ft has many small lenses of carbonate that

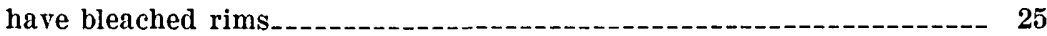

Sandstone, red._._. 20

Slate, red; well-formed cleavage._._. 2

Sandstone, red._-_-_._- 3

Steep fault with quartz veins.

Slate, red.-_-_-_-_- 10

Sandstone, red._._._.

Slate, red ; small carbonate lenses_._. 5

Total -

The Wamsutta Formation appears to be conformable and gradational with the underlying Pondville Conglomerate in the few places where the contact has been observed. Near the contact, gray beds typical of the Pondville Conglomerate are interbedded with red beds. typioal of the Wamsutta Formation. The contact between the two formations is placed where the red beds first predominate.

This formation extends the full length of the Norfolk basin and is also found in the northern part of the Narragansett basin of Massachusetts and Rhode Island. Farther south in the Narragansett basin, it is reported to grade into the lower part of the Rhode Island Formation (Quinn and Oliver, 1962, p. 64). The top of the Wamsutta Formation has been eroded away in the Norwood quadrangle so that its original thickness is unknown, but about 3,000 feet still remains.

\section{CORRELATIONS}

The Pondville Conglomerate and the Wamsutta Formation occur in both the Norfolk and Narragansett basins, and it is probable that these basins were fully merged at one time (Quinn and Oliver, 1962, p. 69). Although the Roxbury Conglomerate of the Boston basin is now only $21 / 2$ miles from the Norfolk basin in the northeastern part of the Norwood quadrangle, there has been considerable uncertainty concerning the correlation of the rocks of the Boston and Norfolk basins. 
Emerson $(1917$, p. 58) considered the Roxbury Conglomerate to be equivalent in age to all the formations of the Narragansett basin. LaForge (1932, p. 39) believed that the rocks of the Boston and Norfolk basins are of the same age because of their closeness, but he did not suggest any correlations.

The writer believes that the Pondville Conglomerate and the Wamsutta Formation of the Norfolk and Narragansett basins correlate with the Brookline Conglomerate and the Dorchester Slate Members, respectively, of the Roxbury Conglomerate of the Boston basin. The Pondville Conglomerate and the Brookline Member are basal units of similar thicknesses and lithology. The Wamsutta Formation and the Dorchester Slate Member have corresponding stratigraphic positions above the conglomerate and similar thicknesses and lithologic characteristics. Particularly significant are the red and distinctive purple and green of these units in both basins. Purple and green slates and siltstones are exposed in the Norfolk basin near the intersection of Neponset Street and the new Route 95 .

\section{DIKES OF DIVERSE AGES}

Dark-colored dikes of mafic rock are numerous in the northern and central parts of the Norwood quadrangle but are less abundant in the southern part. The youngest are olivine diabase dikes which are thought to have been emplaced during Triassic time. The older dikes are highly altered as a result of the regional metamorphism, and most appear to be metadiabase; they were emplaced in Carboniferous and pre-Carboniferous time. The best exposures of these dikes in the Norwood quadrangle are in the large roadcuts along Route 128 northwest of the intersection with Route 1A. All the dikes are too small to be shown on the geologic map.

Mafic dikes of three or more ages are distributed widely in eastern Massachusetts. According to Emerson (1917, p. 261-277, fig. 2, p. 262), diabase dikes occur in all parts of the State, and olivine diabase and normal diabase dikes are numerous east of the longitude of Southboro. Crosby $(1905$, p. 82$)$ recognized two sets of diabase dikes in the Boston area-an east-west set which he considered to be of Carboniferous age and a north-south set which he considered to be of Triassic age. He $(1900$, p. 388$)$ also called attention to dikes he considered to be of pre-Carboniferous age in the Cambrian slate on the north side of the Blue Hills. LaForge (1932, p. 45-50) gave a good description of the diabase dikes of the Boston area north of the Norwood quadrangle. He classified most of the dikes into four sets: (1) an older east-west set of post-Cambrian, pre-Carboniferous age, (2) a 
northwest set of Carboniferous age, (3) a younger east-west set of Carboniferous age, and (4) a north-south set of Triassic age.

Because many of the dikes in the Norwood quadrangle cut the Mattapan Volcanic Complex, they are probably either Carboniferous or Triassic in age (LaForge, 1932). Only two are known to be older than the Mattapan Volcanic Complex.

These older dikes occur in an outcrop of Dedham Granodiorite about 500 feet south of Sprague Street and about 500 feet northwest of the standpipe in the Greenlodge section of Dedham. They both strike about $\mathrm{N} .75^{\circ} \mathrm{W}$. and are vertical. The smaller dike is 3-6 inches wide and is about 6 feet northeast of the larger dike, which is $17-27$ inches wide. The larger dike is exposed for about 30 feet and is abruptly cut off at its northwest end by a remnant of felsite that undoubtedly belongs to the Mattapan Volcanic Complex.

The Carboniferous dikes of the Norwood quadrangle are generally greenish gray, have moderate limonite staining on the weathered surface, and lack spheroidal weathering and columnar jointing. Most are fine grained, and some have scattered small phenocrysts of plagioclase or hornblende or both. These Carboniferous dikes are as resistant or more resistant to weathering than the enclosing rocks. They range from a few inches to about 100 feet wide and are irregular in strike and dip.

In general the Carboniferous dikes are altered so extensively to chlorite, epidote, zoisite, uralite, and sericite that the original feldspars and ferromagnesian minerals are only partly known. The original plagioclase crystals were zoned; relict grains show highly altered cores with less highly altered rims. In a few thin sections the least altered plagioclase feldspar is albite. A small amount of quartz and untwinned orthoclase occur in some dikes. Hornblende is in most of the dikes, and the content ranges from 2 to 25 percent. Magnetite ranges from 0.5 to 7 percent. Chlorite and epidote are abundant and, together with the hornblende, cause the rock to appear greenish gray. Biotite and muscovite are scarce. Pyrite is sparse.

A few of the diabase dikes probably of Carboniferous age intersect one another, and this relation indicates some age difference. An unusually good example of this can be seen at Interchange 55B about 600 feet northwest of Route 109 and is shown in figure 4. Here a nearly horizontal part of one dike is exposed at the bottom of the roadcut. Its top contact, as shown in figure 4, is at the overhang about a foot above the head of the man. The bottom contact is a short distance below the ground level. A vertical dike, about 5 feet wide, cuts the horizontal dike and has chilled contacts against it. The older, horizontal dike is spilitic diabase having about 65 percent albite, $8-10$ 


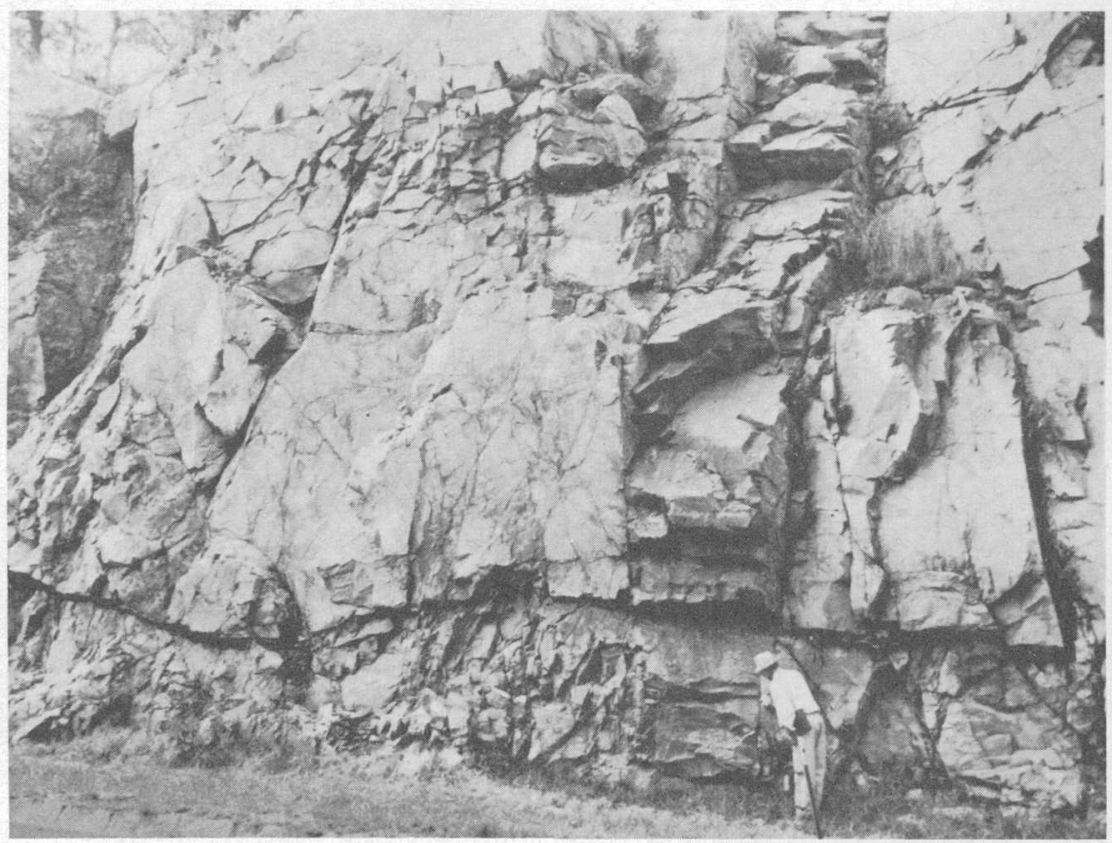

Figure 4.-A vertical Carboniferous metadiabase dike, cutting a nearly horizontal segment of an older spilitic diabase dike. Interchange 55B about 600 feet northwest of Route 109 in an exposure of Salem Gabbro-Diorite.

percent brown and green hornblende, and abundant chlorite and epidote. The albite contains only a few grains of epidote and is relatively fresh; the hornblende is partly chloritized. The diabase in the younger dike is highly altered to epidote, clinozoisite, chlorite, albite, and uralite, and thus is similar to the common Carboniferous dikes.

The Triassic olivine diabase dikes of the Norwood quadrangle are dark gray on fresh surfaces and weather brown. These dikes commonly show spheroidal weathering and columnar jointing (fig. 5). Small dark-greenish-gray serpentinized olivine phenocrysts are visible in hand specimens; feldspar phenocrysts are lacking. The Triassic dikes appear to be less numerous in the Norwood quadrangle than the older dikes, but they weather more rapidly than the surrounding rocks and usually are not exposed in natural outcrops. The abundance of cobbles and small boulders of this diabase in the gravel deposits suggests that the Triassic dikes may be more abundant than the exposures indicate.

The Triassic dike rocks are composed of about 70 percent labradorite in thin tabular crystals $0.15-1.5 \mathrm{~mm}$ long; 20 percent augite, in irregular grains $0.05-0.6 \mathrm{~mm}$ long; and about 10 percent olivine completely altered to serpentine, chiefly antigorite and minor chrysotile. About 


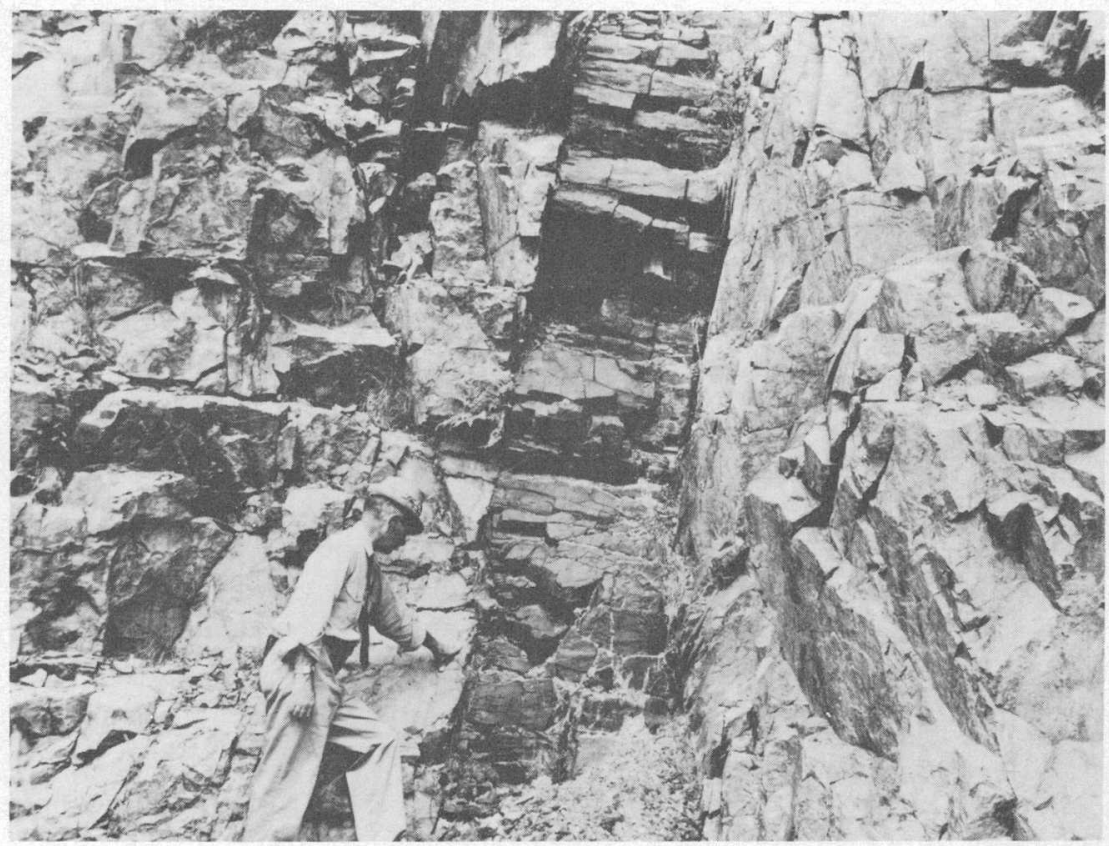

Figure 5.-Triassic diabase dike having columnar structure. Interchange 55A on Route 128 near Route 109.

half the serpentinized olivine occurs as phenocrysts from 1 to $22 \mathrm{~mm}$ in greatest dimension, and half occurs as small anhedral grains in the groundmass. Magnetite is the chief accessory mineral; pyrite is sparse. Except for the olivine, the minerals show very little alteration.

The age of the Triassic dikes is determined by their relation to the enclosing rocks as well as by their unmetamorphosed condition. The roadcut near Route 109 on the northwest side of Interchange 55A exposes two Triassic dikes cutting through a Carboniferous dike. In addition, two small Triassic dikes cut the Pondville Conglomerate in a roadcut on Route 1 about 1,500 feet southwest of the intersection with Dean Street. The minimum age for these dikes is nowhere definitely established; presumably they are related to the block faulting which occurred at the close of the Triassic.

\section{METAMORPHISM}

Two periods of regional metamorphism are recognizable in the rocks of the Norwood quadrangle. The first produced the amphibolites and metarhyolite in the Canton area, and the second, a lower grade metamorphism of the greenschist facies, has affected all the rocks except the Triassic dikes. 
Little is known of the first period of regional metamorphism in this quadrangle. The older rocks that show this metamorphism are exposed in only a few places and have been modified by retrogressive metamorphism. Hornblende was formed in the mafic igneous rocks and biotite in the rhyolitic rocks; these minerals indicate that the rocks may have been metamorphosed as intensely as the amphibolite facies of Turner and Verhoogen (1960, p. 544).

The second period of regional metamorphism has produced albite, epidote, chlorite, and sericite in the rocks of the quadrangle, particularly the mafic rocks. These minerals indicate a low-grade metamorphism of the quartz-albite-muscovite-chlorite subfacies of the greenschist facies (Turner and Verhoogen, 1960, p. 534). Although the metamorphism is of regional extent and can be identified in all the pre-Triassic rocks, it did not reach equilibrium everywhere. Potassium-argon dates obtained from micas in these rocks give a maximum age of 255 million years (Hurley and others, 1960, p. 256-257). This indicates that the metamorphism probably was caused by the late Paleozoic orogeny.

The calcic plagioclase has been affected most and the potassium feldspar and albite the least by this metamorphism. Much of the biotite has been chloritized. Hornblende has been partly chloritized but is less altered than the biotite. The mineral composition has largely determined the extent of the alteration of the different rocks. Those rocks containing quartz, potassium feldspar, albite, sodic oligoclase, and hornblende as principal constituents are least altered, and those containing abundant calcic plagioclase are the most altered. The effect of the mineral composition is illustrated by the usual highly altered pre-Triassic diabase dikes as compared with the slight alteration of the Mattapan Volcanic Complex, the Blue Hill Granite Porphyry, and the Quincy Granite.

Rocks adjacent to younger plutonic igneous intrusions also have been modified somewhat by contact metamorphism. This metamorphism is largely confined to the margins of the intrusions and is readily distinguished from the regional metamorphism of the second period. Besides the introduction of some quartz and alkalic feldspar, one of the more obvious contact metamorphic effects of the granitic rocks, such as the Westwood Granite, is the replacement of hornblende by biotite.

Hydrothermal solutions, circulating along fractures, have altered the principal minerals, except quartz, of many rocks to sericite, chlorite, epidote, and hematite near the fractures, and have redeposited materials as fracture coatings or fillings. 
Sericite occurs adjacent to joints in some exposures of Dedham Granodiorite along Route 128 both northwest and southeast of Route 1 and in the highly sheared outcrops of Dedham Granodiorite on the southwest side of the south pond on Mother Brook at East Dedham. The matrix of the Pondville Conglomerate has been sericitized where it has been sheared. Crosby (1889) noted this type of alteration and referred to the sericite as pinite.

Chlorite, with or without sericite, occurs as coatings on joints, especially shear joints, in the Dedham Granodiorite and Westwood Granite. Along some shear joints and in microbreccia zones, chlorite is the most abundant secondary mineral.

Epidote is common as stringers in fractures and as an alteration product adjacent to the fractures in all the igneous rocks; it occurs in the feldspar as much as several inches away from the fractures.

Hematite is most abundant where the rock is highly fractured, as in the outcrops southwest of the south pond on Mother Brook. The hematite has formed as dark-red coatings on joints, as small spots in the Dedham Granodiorite and Westwood Granite, and as finely disseminated grains in the potassium feldspar. The small spots are at least partly localized by ferromagnesian minerals. The pink variety of Westwood Granite is characterized by very fine grains of hematite irregularly formed in the feldspars.

The alteration product known as unakite, a pink and green rock containing residual quartz, is formed in the Dedham Granodiorite in places. Stringers of unakite, consisting of epidote $1 / 16^{-1 / 4}$ inch wide with borders of reddened potassium feldspar and green epidotized plagioclase $1 / 4$ inch to 2 inches wide were seen in several blocks of Dedham Granodiorite uncovered in excavating gravel at the large pit on the west side of Germany Brook west of Norwood.

Hydrothermal alteration is not associated with all the fractures. Unmineralized joints cut the mineralized joints in places, as is illustrated by the outcrop of Dedham Granodiorite on the north side of Bailey Street southeast of Canton. Here epidotized joints strike about N. $80^{\circ} \mathrm{W}$. and $\operatorname{dip} 70^{\circ} \mathrm{E}$. to vertical and are cut by well-developed nearly vertical open unmineralized joints that strike N. $5^{\circ} \mathrm{W}$.

\section{STRUCTURAL GEOLOGY}

\section{FOLDS}

The amphibolite and metarhyolite of the Marlboro(?) Formation, the oldest rocks exposed in the quadrangle, have northwest strikes and were probably folded by a pre-Late Devonian orogeny. The structures of the Marlboro Formation of the Medfield and Holliston quadrangles also strike northwest, whereas the late Paleozoic structures 
strike northeast (Dowse, 1948, p. 96-97). 'The northwest-trending structures of the Marlboro(?) Formation could be of Precambrian age but in this quadrangle are known only to be older than the intrusion of the Salem Gabbro-Diorite. The rocks in the Norwood quadrangle were also deformed by folding and faulting at the close of the Palezoic Era. The Pondville Conglomerate and the Wamsutta Formation of the Norfolk basin were folded, and the axes of the syncline and associated minor folds trend from N. $50^{\circ}$ to $85^{\circ} \mathrm{E}$. but chiefly N. $65^{\circ} \mathrm{E}$.

West of the Stony Brook fault, the north limb of the syncline is overturned toward the southeast so that the beds dip $50^{\circ}-80^{\circ} \mathrm{NW}$. (pl. 1, sections $A-A^{\prime}$ and $B-B^{\prime}$ ). East of this fault the northwest limb of the syncline is not overturned and the beds dip $65^{\circ}-75^{\circ} \mathrm{SE}$. (pl. 1, section $C-C^{\prime}$ ). Outcrops are scarce on the southeast side of the basin, but the few present indicate that the beds of the southeast limb of the syncline dip northwest and are not overturned.

\section{FAULTS}

The Norfolk basin sedimentary rocks appear to have been cut and displaced by two northerly transverse faults, one, the Stony Brook fault along the Neponset River valley and the other through East Walpole and Dedham. In addition there is evidence that the Norfolk basin and the Roxbury Conglomerate area are partly bordered by reverse faults.

A fault along the Neponset River valley has been postulated for a long time. Loughlin (1911, p. 26) showed it on his map of the Blue Hills area; Billings (1929, p. 100) named it the Stony Brook fault, and Ilsley (1934, p. 22) also thought that a fault must account for the difference in structure on opposite sides of the Neponset valley. The existence of the fault is indicated by the apparent abrupt termination of the lower member of the Pondville Conglomerate at the Neponset River and the change in the northwest limb of the syncline from an upright to an overturned position.

Most of the rock in the outcrops near the Stony Brook fault is considerably fractured and altered. The Mattapan fragmental volcanic rocks and the Dedham Granodiorite exposed in the railroad-cut at the west end of the road bridge over the railroad, 700-800 feet south of the north edge of the quadrangle, are cut by small faults and are complexly jointed. The Dedham Granodiorite is so highly altered to sericite and epidote in places south of the bridge that it is difficult to identify. The Dedham Granodiorite exposed in the railroad-cut just north of Canton Junction is cut and partly granulated by numerous anastomosing shear fractures. On the map the fault is shown to branch about 1,200 feet north of this railroad-cut. One branch trends 
southwest past the east side of Knollwood Memorial Park and the west side of the center of Sharon; the other trends nearly due south past the west side of the center of Canton. The existence of the east branch is inferred from the presence of much fractured aplite and the chloritized Dedham Granodiorite exposed in an excavation 1,100 feet southeast of Canton Junction. This exposure is so highly fractured and chloritized that it must be within the fault zone. Farther south the exposures are inadequate for more than an estimation of the location of the fault.

The west branch is inferred from limited evidence because the fault zone is not exposed. The outcrops of Sharon Syenite on the north side of the Knollwood Memorial Park contain numerous small shear cracks having granulation of the rock along them. Also, some of the outcrops of Sharon Syenite on the Southeast side of Canton Street, opposite the Knollwood Memorial Park, are finer grained than normal owing to granulation of the feldspars by shearing.

The second northerly trending fault passes through East Walpole where the upper member of the Pondville Conglomerate appears to terminate abruptly against the Wamsutta Formation just west of Pleasant Street between Norwood and East Walpole. Also, the Pondville Conglomerate in the southern part of East Walpole, on the west side of the fault, has been displaced northward relative to the conglomerate on the east side of the fault.

These transverse faults probably have predominantly horizontal displacement. In both faults, the west side has been displaced northward relative to the east side.

Reverse faults border the northwest and southeast sides of the Norfolk basin in places. A reverse fault that dips southward borders the south side of the Norfolk basin throughout its extent in the Blue Hills quadrangle. This fault apparently extends into the Norwood quadrangle from the east and ends near or at the Stony Brook fault. No evidence was found of a fault along the northwest border of the Norfolk basin east of the Stony Brook fault.

West of the Stony Brook fault there is evidence for a reverse fault along the north border of the Norfolk basin to and beyond the west edge of the quadrangle. The presence of this fault is indicated by the apparent absence of the lower coarse conglomerate member of the Pondville Conglomerate west of the Stony Brook fault and the apparent absence of the entire Pondville Conglomerate along the northwest border of the basin west of the transverse fault at East Walpole. These relations can best be explained by asuming that the older rocks have been thrust various distances toward the southeast over the edge of the Norfolk basin syncline and that the thrusts conceal some or all of the Pondville Conglomerate of the northwest limb of the syncline. 
Ilsley (1934, p. 144) thought that overthrusting was progressively greater toward the southwest.

The sedimentary rocks exposed along the northwest border of the basin are sheared in zones that in most places strike northeast about parallel to the strike of the faults and dip $20^{\circ}-65^{\circ} \mathrm{NW}$. These shear zones decrease in number and width southeastward and are only slightly developed near the southeast border of the basin., In the northern part of the Norfolk basin west of the Stony Brook fault the matrix of the Pondville Conglomerate in the shear zones is schistose, and pebbles have been stretched from two to four times their normal length. The shearing also formed interlacing cracks in the Wamsutta Formation and changed shale to slate and phyllite.

The wedge of Roxbury Conglomerate in the northeast corner of the quadrangle is probably bordered on the southeast by a fault that strikes northeast. Very likely this fault is a continuation of one of the faults shown by LaForge $(1932$, pl. 1) on the geologic map of the Boston and Boston Bay quadrangles. This fault is shown on the geologic map of the Norwood quadrangle to terminate southwestward at the fault inferred to trend northeast from East Walpole to Dedham. The exact location and southwestward extent of the fault, however, are unknown. A reconnaissance scintillometer survey found some anomalies that aided in locating the fault as shown on the map.

Another fault may extend northwest from the Stony Brook fault along the southwest side of Mother Brook. This fault is probably the continuation of a fault mapped by LaForge $(1932, \mathrm{pl} .1)$ in the Newton quadrangle to the north. The fault is not exposed in the Norwood quadrangle, but its presence is indicated by the highly fractured and altered outcrops of Dedham Granodiorite on the southwest side of the south pond on Mother Brook at East Dedham. The outcrops are so sheared and granulated that the identity of the rock is obscured. The shear fractures have an average strike of about N. $50^{\circ}$ W., which also is the estimated strike of the fault, and they dip from $75^{\circ} \mathrm{NE}$. to $75^{\circ} \mathrm{SW}$. The large outcrop of Dedham Granodiorite on the northeast side of the pond is much less sheared, and, for this reason, the fault is probably near the southwest side of the pond. The fault is also indicated by some of the outcrops that are fractured and altered on the southeast side of the pond at the north border of the quadrangle. These outcrops are reddened by hematite, a further indication of a fault in the vicinity.

The Roxbury Conglomerate is shown on plate 1 as slightly offset by this fault, but the magnitude and kind of fault displacement is not known. Exposures of conglomerate in the railroad-cuts southeast of the probable location of the fault indicate that the displacement is not large. 
LaForge (1932, pl. 1) showed two thrust faults at the north border of the Blue Hills quadrangle that, if extended southwestward, could cross the northwest corner of the Blue Hills quadrangle into the northeast corner of the Norwood quadrangle. One of these is the south border fault of the Boston basin. The writer believes that exposures of quartzite and siltstone between Brush Hill and Canton Avenue in the northwest corner of the Blue Hills quadrangle are Cambrian rather. than the Cambridge Slate. The boundary fault, therefore, probably continues westward in the Boston South quadrangle toward the Hyde Park area instead of turning south west into the Blue Hills quadrangle near Milton Center as shown by LaForge. The second fault, if present, would be on the west side of Brush Hill where outcrops are lacking.

\section{JOINTS}

The spacing and regularity of joints vary considerably in different parts of the quadrangle. Joints are numerous in the roadcuts along Route 128 for a few thousand feet northwest of interchanges 56 and 57 ; many of these joints are curved and show slickensides. The Westwood Granite in and near Norwood has numerous joints in many places. Joints spaced a few inches to a foot apart also were observed in outcrops on the east side of East Dedham, on the west side of Route 1A west of Wigwam Pond (south of Dedham), on the crest of Fox Hill north of Westwood, and in the northern part of Readville Manor in the northeastern part of the quadrangle. In other localities, particularly south of the Norfolk basin and in the Wamsutta Formation in the basin, the joints ure widely spaced.

Where joints are numerous, they may appear to trend in all directions, but in most places two or three prevailing directions of strike can be recognized. Seventy-five strike and dip readings were taken of sets of joints at 39 lncalities throughout the quadrangle. These fall into seven more or less well defined sets as follows:

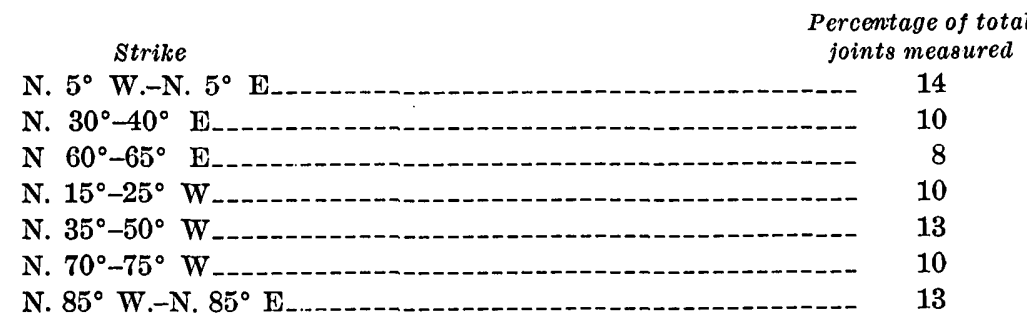

Although these sets usually do not all appear in one outcrop, they are widely distributed in the quadrangle, and none seem to be confined to any one part. Most of the joints have steep dips, but some dip gently. The joints having low dips do not seem to be restricted in distribution. 
Some of the joints in the areas of more intense fracturing show slickensides and actually are small faults. Strongly developed slickensides were observed on joints in Dedham Granodiorite in the roadcuts on the southeastbound lanes of Route 128 for a few hundred feet northwest of Route 1A. In one exposure the slickensides are approximately horizontal on joints that strike northwest. These joints offset northeast joints from a fraction of an inch to 6 inches in a right-lateral sense.

Columnar jointing is common in the Triassic dikes. The best exposures are in the roadcut near Route 109 on the part of the traffic circle connecting Route 109 and the northwestbound lanes of Route 128 (fig. 5).

\section{SURFICIAL GEOLOGY}

Nearly all the deposits of Quaternary age mapped in the Norwood quadrangle are a result of continental glaciation during the Pleistocene Epoch. The effects of the continental glaciation may be divided into two parts: erosion and deposition during the advance of the ice, and deposition and minor erosion during the melting of the ice. The surficial geology of the Norwood quadrangle is shown on plate 2 .

Deposits of only one ice advance are known in the Norwood quadrangle, although local readvances have been described in eastern Massachusetts (Crosby, 1934, p. 149; Judson, 1949; Chute, 1959, p. 197-202; and Kaye, 1961, p. B-73 and table 1). Different types of till are present, but they are considered to be of the same age because no buried soils or other evidence for age difference has been found.

\section{BURIED VALLEYS}

Several deep valleys eroded into bedrock and filled or nearly filled by unconsolidated deposits are known in eastern Massachusetts (Crosby, 1939) and the coastal areas of the New England States (Upson and Spencer, 1961). The valleys were formed by stream erosion prior to the last glaciation and have been somewhat modified by glacial processes (Upson and Spencer, 1961, p. 44).

The unconsolidated sediments in the buried valleys were probably deposited mainly during and at the close of the last glaciation, although some of the more deeply buried sediments may have accumulated before the beginning of the last glaciation. The surface deposits are mostly swamps formed in part during late-glacial and postglacial time.

In the Norwood quadrangle, a buried valley underlies the present surface valley of the Neponset River, and buried tributary valleys underlie Reservoir Pond and Ponkapog Brook, Purgatory Brook, and Wigwam Pond (pl.2). In a few places, test borings and bedrock 
outcrops indicate the approximate position of the main buried valley, but nowhere is the information sufficient to determine its width or greatest depth. The evidence available indicates that there is an older valley floor, probably only a few tens of feet above present sea level, incised by a relatively deep narrow valley to a depth of more than 100 feet below present sea level. Although partly dissected, much of the older floor apparently is still preserved under a thin cover of glacial and postglacial deposits. Outcrops of bedrock south of Norwood Airport and elsewhere are the tops of small hills on this floor.

The axis of the main channel of the buried Neponset River valley is inferred to enter the west side of the quadrangle near the present river channel (pl. 2) and to continue eastward under East Walpole to Neponset Street where it turns northeastward approximately beneath the present course of the river.

Northeast of Route 128 the buried valley probably underlies the Neponset River for about a mile. Farther northeast its location is in doubt. Crosby $(1939$, p. 379) believed that it crossed the northwest corner of the Blue Hills quadrangle along the valley of Trout Brook. Low relief and sparseness of outcrops along the Neponset River in the extreme northeast corner of the quadrangle suggest this as another possible location for the buried channel, but the continuation of the buried channel to the northeast in the Newton and Boston South quadrangles is uncertain.

The present wide surface valley terminates abruptly in the southcentral part of the quadrangle. From there westward the location of the buried valley is uncertain. Crosby $(1939$, p. 375) located it under East Walpole and along the south side of Bird Pond about as shown on plate 2. Seismic measurements by the U.S. Geological Survey about a mile south of East Walpole (pl. 2) showed unusually thick surficial deposits but did not locate the main part of the buried valley in that area.

Complete burial of this part of the valley by glacial deposits may have been caused by such factors as: (1) orientation of the valley at right angles to the direction of ice movement, (2) narrower width of the upper valley in this area, (3) location in an area of generally thick surficial deposits, or (4) presence of high hills just to the south that caused deposition of thick till in the valley area.

Only limited information is available concerning the buried tributary valleys. A deep well at the State Hospital School north of Reservoir Pond penetrated 238 feet of gravel, clay, and till before reaching bedrock about 43 feet below sea level (I. B. Crosby, oral commun.). Crosby $(1939$, p. 379) considered this depth to be evidence of an important tributary valley. The course of this tributary is 
uncertain, but it may trend northward and lie approximately beneath the present course of Ponkapog Brook.

A second Neponset buried valley tributary apparently trends south from the vicinity of Interchange 56 and 57 on Route 128 to Purgatory Brook where it turns southeast beneath the present surface stream. Several wells drilled for Norwood a short distance east of Route 1 near Purgatory Brook show that the bedrock is at least 50 feet below sea level in this area.

Another buried tributary apparently trends north from the vicinity of Wigwam Pond towards the buried valley of the Charles River north of the quadrangle. Two wells in this valley drilled about 150 feet southeast of Route 1 and 2,000 feet south of the north edge of the quadrangle are reported to have ended on either boulders or bedrock a little above sea level.

Although the Wigwam Pond and Purgatory Brook tributaries may connect in the vicinity of Route 128, bedrock exposures at Interchanges 56,57 , and 58 suggest that the tributaries are separated by a bedrock divide. In addition, borings 1500 feet apart at the railroad crossing and Interchange 58, reached bedrock at shallow depths. On the other hand, the apparent alinement of the valleys and the anomalous southward course of the Purgatory Brook buried valley for about $11 / 4$ miles south of Route 128 may indicate a buried valley formed by a stream that flowed from the Charles River buried valley southward to the Neponset River buried valley.

Crosby's map (1939, p. 375) shows a buried tributary valley in Walpole which trends northeast from the southwest corner of the Norwood quadrangle near Washington Street. Topography and lack of outcrops indicate a buried valley here, but without more definite evidence it is not shown on the surficial geologic map (pl. 2).

Glacial erosion of the buried valleys undoubtedly varied with their orientation. Where the glacier flowed parallel to the valleys, as in the Purgatory Brook tributary, it probably eroded most of the older sediments and gouged into the bedrock. Where the glacier moved at right angles to the valleys, it was less effective in removing the older sediments, and some may remain, especially on the lee side of prominent bedrock ridges such as those crossed by Neponset and Canton Streets.

Several deep borings in the Neponset River buried valley (see pl. 2 and table 1) have supplied information on the thickness of postglacial material, sand, gravel, and till.

Little is known about the till in the Neponset River buried valley. It is recognized in driller's logs of boreholes by the large number of blows required for penetration and by boulders. Older sediments may underlie the till in some places, but in other places the till probably rests directly on bedrock. 
The till is overlain by a deposit of sand and gravel (table 1) reported as yellow in some of the boreholes. The irregular upper surface of the sand and gravel and its yellow color suggest that it was partly weathered and eroded before the overlying finer grained gray sand was deposited. More likely the surface irregularities are the result of original deposition as kames or other types of irregular landforms. This sand and gravel deposit may be equivalent to the outwash described by Upson and Spencer (1961, p. 38-39) as overlying till in many of the buried valleys. Too little is known of the deposit in the Neponset River buried valley, however, for its origin and erosional history to be interpreted. The color suggests some subaerial weathering, but part of the yellow sand and gravel is now well below sea level and could have been weathered only when sea level was lower.

TABLE 1.-Materials found in selected borings in the Neponset River buried valley

[Datum is mean sea level]

\begin{tabular}{|c|c|c|c|c|c|c|c|c|c|c|}
\hline \multirow{2}{*}{ Materials } & \multicolumn{2}{|c|}{ Site 2} & \multicolumn{2}{|c|}{ Site 4} & \multicolumn{2}{|c|}{ Site 5} & \multicolumn{2}{|c|}{ Site 6} & \multicolumn{2}{|c|}{ Site 7} \\
\hline & $\begin{array}{l}\text { Alti- } \\
\text { tude } \\
\text { (feet) }\end{array}$ & $\begin{array}{l}\text { Thick- } \\
\text { ness } \\
\text { (feet) }\end{array}$ & $\begin{array}{l}\text { Alti- } \\
\text { tude } \\
\text { (feet) }\end{array}$ & $\begin{array}{l}\text { Thick- } \\
\text { ness } \\
\text { (feet) }\end{array}$ & $\begin{array}{l}\text { Alti- } \\
\text { tude } \\
\text { (feet) }\end{array}$ & $\begin{array}{l}\text { Thick- } \\
\text { ness } \\
\text { (feet) }\end{array}$ & $\begin{array}{l}\text { Alti- } \\
\text { tude } \\
\text { (feet) }\end{array}$ & $\begin{array}{l}\text { Thick- } \\
\text { ness } \\
\text { (feet) }\end{array}$ & $\begin{array}{l}\text { Alti- } \\
\text { tude } \\
\text { (feet) }\end{array}$ & $\begin{array}{l}\text { Thick- } \\
\text { ness } \\
\text { (feet) }\end{array}$ \\
\hline $\begin{array}{l}\text { Fill, muck, and } \\
\text { peat. }\end{array}$ & $\begin{array}{l}41.6 \\
\text { to }\end{array}$ & 3.5 & $\begin{array}{l}42.2 \\
\text { to }\end{array}$ & 10 & & & $\begin{array}{l}46.4 \\
\text { to }\end{array}$ & 7 & & \\
\hline $\begin{array}{l}\text { Coarse sand and } \\
\text { gravel. }\end{array}$ & $\begin{array}{l}38.1 \\
38.1 \\
\text { to } \\
23.6\end{array}$ & 14.5 & $\begin{array}{l}32.2 \\
32.2 \\
\text { to }\end{array}$ & 4 & $\begin{array}{l}38 \\
\text { to }\end{array}$ & 4 & $\begin{array}{l}39.4 \\
39.4 \\
\text { to }\end{array}$ & 20 & $\begin{array}{l}42.5 \\
\text { to }\end{array}$ & 9.5 \\
\hline Fine sand.- & $\begin{array}{r}23.6 \\
23.6 \\
\text { to } \\
-28.9\end{array}$ & 52.5 & $\begin{array}{r}28.2 \\
28.2 \\
\text { to } \\
-68.8\end{array}$ & 91 & $\begin{array}{r}34 \\
34 \\
\text { to } \\
-1\end{array}$ & 35 & $\begin{array}{r}19.4 \\
19.4 \\
\text { to } \\
-88.1\end{array}$ & 107.5 & $\begin{array}{r}33.0 \\
33.0 \\
\text { to } \\
-77.5\end{array}$ & 110.5 \\
\hline Sand and gravel... & $\begin{array}{r}-28.9 \\
-28.9 \\
\text { to } \\
-40.4 \\
-40.4\end{array}$ & 11.5 & & & $\begin{array}{r}-1 \\
-1 \\
\text { to } \\
-12\end{array}$ & 11 & $\begin{array}{l}-88.1 \\
-88.1 \\
\text { to } \\
-95.6\end{array}$ & 7.5 & $\begin{array}{l}-7.0 \\
-77.5 \\
\text { to } \\
-81.0\end{array}$ & 3.5 \\
\hline Bedrock or & $\begin{array}{r}\text { to } \\
-53.4\end{array}$ & & & & & & -95.6 & & -81 & \\
\hline boulders. & & & & & & & & & & \\
\hline
\end{tabular}

A thick deposit of fine gray sand that has some intermixed clay and fine gravel overlies the yellow sand and gravel deposit and constitutes the major volume of sediments in the parts of the buried valleys that underlie the Neponset River and Purgatory Brook marshes; however, this sand is not found elsewhere in the buried valleys. Its greatest thickness shown by the boreholes is about 120 feet, and its greatest known depth below sea level is about 88 feet. This sand is probably a late-glacial deposit formed in a lake that coincided in extent with the present Neponset River and Purgatory Brook marshes. The lake was about $61 / 2$ miles long and had an area of about $51 / 2$ square miles. Its surface was not higher than about 50 feet above present sea level.

The estuarine deposits of clay, silt, sand, and peat in the Boston area were laid down during the last rise in sea level. These deposits 
(Upson and Spencer, 1961, fig. 4, p. 42) extend as much as 90 feet below sea level. Although boreholes show that the fine sand in the Neponset buried valley extends to at least 88 feet below present sea level, it does not appear to be an estuarine deposit connected with those in the Boston area. No channel low enough to allow sea water to enter the Neponset River valley is known north and northeast of the Norwood quadrangle. The fine sand deposit probably formed in an isolated lake that was dammed by glacial deposits. This lake was eventually filled and obliterated.

The fine sand grades upward in the central part of the quadrangle into a few feet of coarser sand and gravel, usually overlain at the surface by a few feet of peat (table 1), which formed as the final deposit in the buried valley. In places, a few feet of black fine-grained peat formed first and is overlain by brown fibrous peat containing scattered lenses of diatomite.

\section{GLACIAL EROSION}

Glacial striae on bedrock surfaces in various parts of the Norwood quadrangle show that ice movement was S. $15^{\circ}$ E.-S. $30^{\circ}$ E. Similar directions were found in the Blue Hills (Chute, 1940, p. 16) and Brockton quadrangles (Chute, 1950).

Glacial erosion was sufficient in the Norwood quadrangle to remove the unconsolidated mantle rock and some of the bedrock. No deeply weathered bedrock, such as occurs in the Slocum quadrangle (Power, 1957) in southern Rhode Island, was found.

Glacial erosion does not appear to have greatly modified the preexisting stream-eroded topography in most places. In areas of abundant rock exposures, as in the northwestern part of the quadrangle, the bedrock surface is a complex of small knobby hills 20-150 feet high, separated by small steep-sided stream-eroded valleys that trend in various directions. This topography was mainly formed by preglacial stream erosion rather than by glacial erosion.

\section{GLACIAL DEPOSITS}

\section{UNSTRATIFIED DEPOSITS}

The unstratified deposits are composed of till, a mixture of mineral and rock fragments of all sizes ranging from clay to large boulders. Of the different types of till deposits, ground moraine, drumlins, and flowtill are represented in the Norwood quadrangle.

GROUND MORAINE

The irregular layer of till that overlies the bedrock in most places throughout the quadrangle constitutes the ground moraine. It not only is the surface deposit over nearly 50 percent of the quadrangle but 
also probably underlies most of the other surficial deposits. The ground moraine was deposited in part by and underneath the advancing glaciers and in part as a residual deposit from the melting ice.

The thickness of the ground moraine varies in different parts of the quadrangle. In much of the northwestern part, at Readville Manor, in the northern and eastern sections of Norwood, in the vicinity of Canton, and in a few other localities, bedrock outcrops are numerous, and the ground moraine is thin or absent. Elsewhere, as along the west side of the quadrangle south of the center of Westwood, the scarcity of outcrops suggests thicker ground moraine.

Borings at the site of a proposed bridge over Coney Street in Walpole, about 300 feet northwest of the town line, show unusually thick ground moraine. According to the driller's $\log$ s, four of the borings penetrated 60 feet of compact stony material, undoubtedly till, without reaching bedrock or the bottom of the till. Seismic traverses made by the Geological Survey along the proposed Interstate Highway 95, southwest of the present intersection of High Plain Street and Moose Hill Street in Sharon (pl. 2), show that in most places along this part of the traverse lines the till is more than 50 feet thick and in some places is 100-125 feet thick. These areas of unusually thick till are on the north and northwest sides of high bedrock hills which probably caused the deposition.

The streamlining of many hills in the direction of ice movement indicates that much of the ground moraine was deposited and shaped underneath the ice while the ice was in motion. This streamlining action is well illustrated in the northwestern part of the quadrangle by the marked difference between the irregular knobby bedrock topography on the northwest side of High Street and the smoothly undulating ground-moraine topography on the southeast side. Fox Hill in Westwood is a good example of a bedrock hill streamlined by subglacial deposition and molding of ground moraine.

Some of the till at the surface of the ground moraine was deposited as the ice became stagnant and melted. This till is commonly more sandy and less compacted than the till deposited beneath the ice, partly because it was not compressed by the weight of the ice and partly because of the removal of some of the clay and silt by melt water before and during deposition. Small lenses of sand and gravel are common in this till. In places, as at the western end of Ellis Pond on the west side of Norwood, most of the finer material was washed from the till and a concentration of boulders remains.

Most of the till of the ground moraine, particularly the part deposited subglacially, is of local derivation and has been transported only relatively short distances; therefore, the composition and physical 
properties of the ground moraine are determined largely by the local bedrock from which the till was derived. The bedrock in the Norwood quadrangle consists mainly of volcanic, granitic, and dioritic igneous rocks that produce gray sandy till, but the red sandstone and shale of the Wamsutta Formation produce red till which occurs in and south of the Norfolk basin.

The till of the ground moraine in eastern Massachusetts has been interpreted by some geologists to be of two ages (Hansen, 1956, p. 61) and to have been formed by separate ice advances. The writer, however, believes that the till observed in the Norwood quadrangle is of one age and that the variations in it are the result of such factors as the source of the till, the amount of silt and clay removed by melt water before and during deposition, and the effects of weathering.

\section{DRUMLINS}

Drumlins are oval hills composed of till and elongated parallel to the direction of ice movement. The Norwood quadrangle has only three small drumlins. These drumlins are all in the northeast corner of the quadrangle, at the border of the drumlin field in the Boston basin which Crosby (1934, p. 138) estimated to contain about 180 drumlins.

The easternmost of the three drumlins is about 2,300 feet long, 1,300 feet wide, and 70 feet high. The north half of this drumlin is in the Newton quadrangle. Some loose sandy till was observed at the top of the drumlin, but excavations in its south end expose compact brown oxidized till containing thin layers of fine sand and silt in places. The sand and silt layers are interbedded with thin till layers, and are exposed at intervals of about 200 feet on the southeast side of the drumlin. These sand and silt layers occur in two or three zones about 5-10 feet thick. One or two zones were exposed near the base of the drumlin; at one time the southwest end of one of these zones was traceable for 75 feet in the face of the excavation. Another zone was partly exposed near the top of the excavation about 40 feet above the base of the drumlin.

Most of the sand and silt layers are thinly laminated and are only an inch to a few inches thick. These are separated by layers of unstratified and unsorted till-like material a few inches to a few feet thick.

The middle drumlin is about 1,500 feet long and rises about 65 feet above the adjacent area on the east and about 25 feet on the west. Exposures in a sand and gravel pit in the north end of the drumlin show that it is underlain by well-stratified sand and pebble gravel. From 15 to 20 feet of sand and gravel underlies 30-35 feet of till. The contact between the till and the underlying sand and gravel is 
fairly sharp and broadly undulatory. Except for the top 3 feet of the sand in which the stratification has been destroyed, bedding is distinct and dips $10^{\circ}-15^{\circ} \mathrm{SW}$. Several clastic dikes a few inches wide composed of fine sand and silt cut across the bedding of the sand at a steep angle. The beds are also cut and displaced a few inches by two normal faults that dip northeast. Above the sand and gravel, in the basal 8 feet of the till, are many irregular remnants of light-bluishgray unoxidized till. These remnants are a few inches to a few feet long and contrast strongly in color with the yellowish-brown oxidized till. Before the pit was enlarged, some poorly sorted coarse gravel lenses could be seen in the upper part of the till of the drumlin. Also, part of a steeply tilted layer of sand several feet thick shoved up from the underlying sand was exposed in the lower part of the till. The internal composition of the westernmost drumlin was not observed. Presumably it is similar to the other two.

\section{FLOWTILL}

Flowtill, as defined by Hartshorn (1958), consists of a thin layer or layers of till on or interstratified with bedded sediments. Hartshorn interpreted the flowtill to have formed as mudflows sliding from adjacent ice onto stratified deposits; sometimes these tills are covered by later layers of stratified sediments.

Flowtill is exposed at the top of the gravel pit on the northwest side of Route 1 southeast of Tralpole Heights. Another exposure of probable flowtill is in a pit in the northeast corner of the quadrangle, at the south end of the east drumlin. Here very thin layers of till-like material are interstratified with very thin layers of fine sand.

\section{STRATIFIED DEPOSITS}

Approximately 30 percent of the Norwood quadrangle is covered by glacial deposits composed chiefly of sand and gravel. These deposits were formed during the final stages of the melting of the ice sheet, after the ice had thinned sufficiently to become stagnant. The ice first melted from the higher hills and, as melting continued, separated into irregular blocks that gradually shrank in size and disappeared.

The glacial stream deposits have not been divided into sequences, as has been done in some quadrangles (Jahns, 1951), because of the complexity of the glacial drainage.

\section{KAMES AND KAME FIELDS}

Kames are widely distributed in the Norwood quadrangle. They are ice-contact deposits of sand and gravel commonly deposited by streams on or adjacent to wasting glacier ice. Some are steep-sided isolated 
conical hills, but they vary in size and shape and may occur singly or in groups called kame fields. The irregular subsidence that took place as the ice melted destroyed the original forms of the deposits and left them with a knobby topography which is the principal characteristic of kame fields. Boulders are common in kames, especially where the kames were in contact with the ice masses.

The kame field in the southeastern corner of the quadrangle is part of a large kame field that extends into the Blue Hills, Brockton, and Mansfield quadrangles. This kame field and the associated stratified glacial deposits were considered by Fuller $(1904$, p. 185) to have been deposited in Stoughton Bay of glacial Lake Neponset, a body of water originally postulated by W. O. Crosby (Crosby and Grabau, 1896, p. 128). Fuller (1904, p. 184) differed from Crosby, however, in the belief that the deposits formed in separate lakelets rather than in a single large lake.

The large kame field in the south-central part of the quadrangle, west of Canton, was deposited on or along the edge of a large ice block that occupied the Neponset valley. As the ice melted, the sand and gravel settled and formed knobby kame topography in some places and broadly undulating topography in others. Several more kame fields of similar origin and topography occur along the sides of the Neponset River valley. Most of the kame field between Willett Pond on the north and Plimpton and Bird Ponds on the south also has a broadly undulating surface. This topography probably resulted from deposition of sand and gravel over ice of more uniform thickness than in the areas of knobby kames.

\section{ICE-CHANNEL DEPOSITS}

Crevasse fillings (deposits formed by streams in open channels in the ice) and eskers (deposits formed by streams in tunnels in the ice) are grouped together as ice-channel deposits. In the Norwood quadrangle the ice-channel deposits are about 1,000 feet-13/4 miles long, 10-60 feet high, and $50-400$ feet wide. Most of the deposits are sinuous segmented coarse-gravel ridges having uneven crestlines; some are branched.

The ice-channel deposit in the north-central part of the quadrangle east of Islington crosses a low divide. It rises southward from an altitude of about 100 feet at its north end, west of Little Wigwam Pond, to nearly 150 feet at the divide. Just south of the divide it branches, and the west branch descends to an altitude of about 100 feet at its south end, whereas the east branch rises to about 185 feet before terminating. The small ice-channel deposits west and north of Wigwam Pond may be northern extensions of this deposit. Most of this ice-channel deposit has been excavated for gravel. 
The ice-channel deposit at the eastern edge of the quadrangle, north of Reservoir Pond, contains an unusual amount of silt and clay. Pits for half a mile northwest from Washington Street expose mostly "dirty" pebble and cobble gravel containing scattered small boulders. From the surface to the lowest exposures, 25-30 feet below the surface, silt and clay coat the stones and partly fill the spaces between them. Sufficient silt and clay are present to bind the gravel into a coherent mass that stands in vertical faces in the pits. The silt and clay may have been deposited in the gravel during times of reduced streamflow. Subsequently the clay and silt may have been partly redistributed by circulating ground water. The crossbedding shows that the icechannel deposit was formed by a stream that flowed southward. Much of this ice-channel deposit has been excavated for fill.

The ice-channel deposit that borders the west side of Willett Pond rises southward from an altitude of about 145 feet at its north end to about 190 feet near its south end. About 1,000 feet of this deposit, opposite the south end of Willett Pond, has been excavated for gravel.

The ice-channel deposit in the northwestern corner of the quadrangle, on the west side of Rock Meadow Brook, is wider and more irregular in width than the rest of the ice-channel deposits in the quadrangle. About 1,000 feet of the south ond of the deposit has been excavated, exposing large boulders as much as 15 feet across that probably fell into the deposit from the adjacent ice.

The two ice-channel deposits in the southeastern corner of the quadrangle may be branches of a single ice-channel system. They are $0.6-$ 0.7 mile long and terminate southward in a kame field. The wide parts of the northern half of the eastern ice-channel deposit are composed mostly of sand and fine gravel, but the narrower southern half contains much coarse gravel and some boulders. The western ice-channel deposit contains a high percentage of medium to coarse gravel and boulders. The north end of this deposit, between Bay Street and Main Street, has been excavated.

A segmented ice-channel deposit half a mile long follows the bottom of a small north-south valley between Edge Hill Road and Bullard Street northwest of Sharon. This deposit rises from an altitude of about 110 feet at its north end to about 210 feet at its south end, where it terminates in a kame. No pits have been opened in this deposit, and its composition and structure are not known.

The small ice-channel deposits in the kame area on the east side of Moose Hill at the south border of the quadrangle are branches of an ice-channel system. No pits have been opened in these deposits, but sand and some fairly coarse gravel are exposed at the surface. 


\section{KAME TERRACES}

Kame terraces are deposits of sand and gravel formed between residual ice masses and the sides of valleys. As the ice melted, the deposits were left on the valley sides in the form of terraces. Most. of the kame terraces in the Norwood quadrangle are small and irregular.

$\Lambda$ series of kame terraces partly surround the till-covered hills at Walpole Heights in the south western corner of the quadrangle. These kame terraces are irregular and poorly formed, probably because of deposition over the edges of irregular ice masses and frequent shifting of the level of deposition. The terraces are composed of pebble and cobble gravel containing some interbedded sand. A large gravel pit on the north side of High Plain Street, a few hundred feet east of Route 1, exposes horizontal beds of pebble and cobble gravel containing some interbedded pebbly sand and a few boulders. The local direction of deposition, as indicated by the crossbedding, was mainly eastward and northeast ward.

Horizontal beds of pebble and cobble gravel containing some interbedded coarse and fine sand were exposed temporarily in a ditch 10-12 feet deep along the center of Washington Street, 2,000-2,500 feet northeast of High Plain Street. The crossbedding here also dips northeastward.

Many of the pebbles and cobbles in the gravel of these terraces show very little rounding and resemble the stones in till. This resemblance was particularly noted in exposures along Washington Street. The angularity of the stones indicates that some of the gravel has been transported only short distances by streams. The pebbles and cobbles of the gravel exposed in the large pit on the northeast side of the intersection of High Plain Street and Route 1 are somewhat more rounded. It was estimated that $5-10$ percent show no rounding, 5-10 percent are well rounded, and the rest show varying degrees of rounding.

The kame terrace on the west side of Germany Brook west of Norwood may be partly a delta; a large pit in it exposes 8-15 feet of horizontally bedded pebble and cobble gravel containing some sand and a few boulders. On the east side of the pit about 7 feet of sand is exposed beneath the gravel. The beds of sand dip southward and may be delta foreset and bottomset beds. To what extent this deposit is of deltaic origin is uncertain as the gravel exposed in the pit is thicker than usual for topset beds and the beds that resemble delta foreset beds are exposed only in one small part of the pit.

The southward dip of the crossbedding and the decrease in the coarseness of the gravel in the same direction show that the deposit was formed by southward-flowing streams. Here also, many of the 
pebbles and cobbles are about as angular as those found in till, and their angularity indicates very little stream transport before deposition.

Several small kame terraces border the east side of Mill Brook north of Willett Pond and extend southward around the north end of the pond. A small pit on the north side of Nichols Street, at the southeast end of the terraces, exposes sand containing some pebble gravel. The beds dip southward and resemble foreset beds of a delta, but, in the absence of other exposures of the internal structure of these terraces, the extent of the delta is not known.

The kame terraces along Rock Meadow Brook in the northwest corner of the quadrangle are composed of horizontal beds of pebble and cobble gravel containing scattered boulders and variable amounts of sand. The terraces were deposited by southward-flowing streams of melt water that also formed the outwash plain to the south. Two terrace levels have been differentiated on the east side of the brook, one at an altitude of about 210 feet and the other between 220 and 240 feet. The ice-contact margins of these terraces are very irregular owing to deposition against an irregular ice mass that existed in the center of the valley.

\section{KAME PLAINS}

Kame plains are relatively flat-topped deposits of sand and gravel bounded completely or almost completely by ice-contact slopes. Several relatively large kame plains border the Neponset River valley, and a few small ones are in the southeast, south west, and north-central parts of the quadrangle. Most of these kame plains contain sand and gravel pits exposing topset and foreset bedding that indicates they are deltas.

The six small kame plains in the southeastern corner of the quadrangle and the large one west of Canton are all deltas 50-100 feet or more in thickness that have summit altitudes of about 220 feet. The similarity of their altitudes indicates that these deltas were deposited in small interconnected lakes. The topset beds of these deltas are about 3-5 feet thick and consist of pebble gravel, containing some cobbles and interbedded sand. The foreset beds are composed of sand and minor amounts of pebble gravel.

The direction of dip of the foreset beds indicates the local direction of deposition, but this direction varies considerably from place to place in a deposit. At the pits in the kame plain in the southeast corner of the quadrangle, east of Town Pond, the foreset beds dip westward; at the north end of the kame plain on the west side of Town Pond they dip northeast; at the west end of the kame plain between Sharon and West Stoughton they dip southwest; at the northwest side of the kame 
plain east of the south end of Bolivar Pond they dip westward; and at the pits of the small kame plain east of the center of Bolivar Pond they dip northward. The internal structure of the large kame plain southwest of Canton is poorly exposed. A pit across the road to the south from the Chestnut Tree Cemetery north of the center of Sharon exposes foreset beds that dip northwest on the west side of the deposit and northeast on the east side.

The kame plain northwest of Pinewood Pond is within the limits of Fuller's East Sharon Lake (Fuller, 1904, fig. 1), but it has a surface altitude of about 220 feet and probably formed when the lake had fallen to the 220 -foot level. The other kame plains and most of the remainder of the kame field in the southeastern part of the Norwood quadrangle also probably formed in lakes at this level.

The large kame plains that overlie hills adjacent to the Neponset River valley are deltas having surface altitudes that range from 150 to 200 feet, and their altitude indicates that they were formed in separate unconnected lakes. No evidence was found of the existence of a single large lake in the Neponset River valley above an altitude of 60-70 feet.

The large kame plain on the east side of the Neponset River valley north of Canton has three different levels that indicate repeated lowering of lake level as the kame plain grew. The highest level, which has an altitude of 200 feet, is at the eastern edge of the quadrangle. It is bordered on the west by a 180-foot level that extends to near the junction of Chapman and Washington Streets. Farther west along Chapman Street and to the north along Dedham Street is a 160- to 170-foot level. Large pits have been opened in the east and northwest sides of this kame plain, and they expose delta topset beds composed of pebble and cobble gravel and sand underlain by foreset beds composed chiefly of sand and a few ice-rafted boulders.

The part of this kame plain that borders Dedham Street may overlie a bedrock ridge as do the other large kame plains adjacent to the Neponset River valley. No till or bedrock is exposed in the pits at the northwest end of the kame plain, but till was uncovered on the floor of the large pit on the northeast side of Dedham Street at an altitude of 100-110 feet.

The kame plain crossed by Neponset Street on the west side of the Neponset River valley was deposited on a bedrock ridge in an icecontained lake. The lake level stood at an altitude of about 170 feet while the northern part of the kame plain was deposited; it gradually lowered to 140 feet during the deposition of the southern part. A large pit has been dug in the southeast end of this deposit on the southwest side of Neponset Street. Till and bedrock exposed on the floor of the pit shows that the kame plain here was only 10-20 feet thick. 
The large kame plain on the west side of the Neponset River valley, adjacent to Route 128, was also deposited on a till-covered bedrock ridge but does not completely cover the ridge. Initially the lake level stood at an altitude of about 185 feet, then gradually lowered to about 160 feet as deposition proceeded. The large pits on the northeast, southeast, and southwest sides of this kame plain expose delta topset and foreset beds. The pit on the northeast side exposes topset beds 3-4 feet thick composed chiefly of pebble gravel underlain by foreset beds composed chiefly of sand. The foreset beds dip about $25^{\circ} \mathrm{E}$. The pit had been worked southwestward to within 300 feet of the till boundary at the top of the hill, exposing till on the bottom and sides of the southwestern part of the pit. Till is also exposed in the southeastern part of the pit. Till and bedrock are exposed on the floor of the eastern part of the large pit at the southeastern side of this kame plain. The till-bedrock surface rises westward under the kame plain. Till areas at the surface and the steep ice-contact slopes on the south and east sides of this kame plain show that it nearly or completely filled the water body in which it was deposited. Most of the west side of this kame plain, west of Canton Street, is a thin deposit of sand and gravel laid down on a wedge of ice.

The long narrow kame plain crossed by Route 1 northeast of Norwood was deposited as a delta in a chasm in the ice a little over a mile long, probably about the same time that the kame plain to the east was deposited. Many pits have been opened in this kame plain, and the northwest end, on the west side of Route 1, has been almost completely excavated. Delta foreset beds, having northwest, west, and southwest dips, were well exposed during its excavation. The kame plain is younger than and was deposited over the ice-channel deposit that seems to join its southeast end. The chasm in the ice in which the kame plain was deposited may have originated by enlargement of the channel in which the ice-channel deposit was formed.

The kame plain on the southeast side of Wigwam Pond in the northcentral part of the quadrangle, called the Wigwam plain by Clapp (1904, fig. 2), is a delta having a surface altitude of about 120 feet in the northern part and 110 feet in the southern part. Delta topset beds composed of pebble gravel, and foreset beds composed chiefly of sand were formerly exposed in a large pit and in a roadcut at the south end of the deposit. The foreset beds dip southward and eastward.

\section{DELTA OUTWASH PLAIN}

The delta crossed by Route 128 on the east side of the Neponset River valley was formed by a stream that flowed westward along the south side of the Blue Hills. This delta extends eastward into the Blue Hills quadrangle where it grades into an outwash plain and is very 
similar to the delta outwash plain mapped by Jahns (1951) in the Mount Toby quadrangle. Only the delta part of the deposit is in the Norwood quadrangle. The topset beds of the delta, formerly exposed in the abandoned gravel pit north of Route 128, consist of 5-8 feet of horizontal beds of pebble and cobble gravel containing a few boulders and sand lenses. The underlying westward-dipping foreset beds contain more sand and less gravel than the topset beds. Seismic traverses made by the Geological Survey show that the delta ranges from 45 to 75 feet in thickness along Route 128 south of the pit.

The surface of the lake in which the delta was deposited probably had an altitude of about 170 feet and remained close to this altitude during the formation of the delta. The southwestern part of the large kame plain north of Canton has a similar altitude, but there is no other evidence that the two deposits formed in connected lakes.

\section{ALIUVIAL FANS}

Several coalescing alluvial fans cover the steep west front of the delta outwash plain below an altitude of about 100 feet. The fans are composed of sand and gravel eroded from the ravines that dissect the edge of the delta. Test holes dug 2-5 feet deep in the fans exposed pebble gravel containing some cobbles similar to the material in the upper part of the delta. The ravines and fans probably originated soon after the lake in which the delta was deposited had drained because there is no evidence of recent erosion.

\section{OUTWASH PLAINS}

Outwash plains are relatively flat-topped well-stratified deposits of sand and gravel formed by streams of glacial melt water. The broad low areas that they occupy and the kettle holes, such as the one occupied by Buckmaster Pond, show that they formed late in the glacial sequence but before all the ice had melted. The grain size and the amount of gravel composing the outwash plains usually decrease in the direction of melt-water streamflow.

The outwash plains at Dedham, Readville, Westwood, and Norwood have been utilized extensively for residential and commercial developments, and few exposures remain. Because exposures are few, little is known about the composition and structure of the outwash at Dedham. The outwash plain at Readville also has been largely built up, but a large abandoned pit on the southeast side of the railroad at the county line exposes sand and pebble gravel containing scattered cobbles to a depth of 10-12 feet. The sides of the pit are slumped, obscuring the structure. An excavation about 1,000 feet northeast of the Hemenway School exposed 3 feet of fill underlain by 1 foot of pebble gravel and 6 feet of sand to the bottom of the excavation. 
Another excavation nearby is said to have been in sand intermixed with some gravel to a depth of 21 feet. The outwash plain in Westwood was formerly worked for gravel on the west side of Buckmaster Pond. The pit exposed horizontal beds of pebble and cobble gravel having small sand lenses and a few small boulders to a depth of 5 feet. According to the Norwood Water Department, a well 70 feet deep at Buckmaster Pond is in gravel, clay, and till. The outwash plain on the south side of Norwood formerly had several small pits both north and south of Dean Street that exposed pebble gravel containing a few cobbles and some sand to a maximum depth of 8 feet. Residential developments and industrial plants now cover most of this outwash plain.

\section{UNCLASSIFIED SAND AND GRAVEL DEPOSITS}

The unclassified sand and gravel deposits are the deposits of lateglacial origin on the bottoms of ice-block holes and late-glacial drainage channels. The deposits formed as the last of the glacial ice melted after the deposition of ontwash had largely ceased. Deposits of this type occur around the sides of the ice-block depression occupied by Pinewood Pond in the southeast corner of the quadrangle, on the floor of the ice-block depression in the kame terrace west of Sharon, and in places along the sides of Neponset River and Purgatory Brook valleys.

\section{VARVED LAKE CLAYS}

A few exposures of varved clay, containing alternating thin layers of silt and fine sand, were found in the Norwood quadrangle but were too small to be shown on the map. A pit on the north side of the small kame terrace in the southern part of Norwood, 2,000 feet northeast of the junction of Sumner and Pleasant Streets, formerly exposed 7 feet of varved clay for a horizontal distance of 100 feet. This clay was overlain by 2-6 feet of sand and 3-5 feet of pebble gravel containing some cobbles. Varved clay was also seen at two places a short distance west on the opposite side of the railroad. One exposure, a cut about 100 feet long behind a factory building 900 feet northeast of the junction of Mylod and Washington Streets, exposed 10 feet of varved clay. The other exposure, a shallow trench on the south side of the Endean Playground on the west side of Washington Street, exposed 3 feet. The bottom of the clay was not visible at either exposure, and the total thickness is not known.

Several other small exposures of varved clay of unknown thickness and extent were found in the quadrangle. A dug well about 300 feet northwest of the northwest corner of Pinewood Pond, in the southeast corner of the quadrangle, exposed 6 feet of sand and gravel underlain by 4 feet of varved clay to the bottom of the well. Approximately 3 
feet of varved clay was exposed in the bottom of a gravel pit on the east side of Willett Pond about 700 feet north of its south end. In a small exposure near the northwest end of the large kame plain crossed by Dedham Street northwest of Reservoir Pond, a few ice-rafted pebbles were seen in the clay.

\section{EOLIAN DEPOSITS}

An unmapped discontinuous layer of unstratified yellowish-brown wind-deposited silt, in places intermixed with some sand and stones, overlies all types of glacial deposits in the quadrangle. In most places it is 1-2 feet thick, but in depressions it may be as much as 5 feet. The grain size and lack of stratification, together with the common occurrence of ventifacts in or immediately below, indicate that the deposit is mostly eolian (Smith and Fraser, 1935). Deposition probably occurred mainly during the closing stages of deglaciation before vegetation completely covered the area. A dark-gray to black soil 6-10 inches in thickness has formed since deposition.

\section{WEATHERING OF THE GLACIAL DEPOSITS}

During the weathering process, minerals undergo chemical changes that bring them into equilibrium with the surface atmospheric environment. The extent of oxidation and leaching of iron minerals are the most useful indicators of weathering, but the disintegration of some rocks and the formation of calcite also are indicators. Thwaites $(1957$, p. 61$)$ noted that "oxidation by percolating waters which contain dissolved oxygen is one of the first processes to affect the drift; therefore, the oxidized zone extends deepest." $\mathrm{He}$ also said that "leaching or solution involves the removal of soluble material and extends to a less depth than oxidation. The substances dissolved are various but those most commonly and readily noted are (a) iron, (b) manganese, and (c) calcium and magnesium carbonates." The drift in the Norwood quadrangle has sufficient ferrous iron-bearing minerals to produce limonite stains where the drift is oxidized, but readily oxidizable manganese minerals are scarce, and no limestone is found.

Slight but fairly deep weathering characterizes all the glacial drift in eastern Massachusetts. Denny $(1958$, p. 87$)$ said that weathering extends to at least 10 feet below the surface in the Canaan area, New Hampshire. In the Boston area the till of the drumlins is oxidized to a depth of 20 feet or more (Crosby, 1934, p. 152-153). Weathering extends correspondingly deep in the Norwood quadrangle in all types of glacial deposits; cut sufficiently deep to expose unoxidized till, sand, and gravel are scarce.

The amount of limonite staining varies considerably in till and in sand and gravel deposits because of such factors as the following: 
(1) Topography and its effect upon the position of the water table which in turn controls the extent of introduction or removal of limonite, (2) quantity of easily oxidizable minerals, such as pyrite, biotite, and olivine; and (3) amount of silt and clay. Till containing abundant easily oxidizable iron minerals is heavily stained; till containing few of these minerals is slightly stained. For a given amount of limonite, the intensity of the color is greater in deposits rich in clay and silt than in deposits poor in clay and silt. Limonite is transported by percolating ground water and therefore may be removed from the upper part of a deposit and redeposited in the lower parts.

The removal of limonite from both till and gravel deposits results in the formation of a leached zone 1-5 feet thick below the soil zone. Two types of leached zones are common. One of these zones-most common in relatively permeable sandy till and gravel-results from fairly uniform leaching through a thickness of 1-5 feet below the topsoil. The other zone-most common in silty till and clay where the subsurface drainage is poorer-results from localized leaching in small irregular patches; this leaching produces a mottled effect. The localized leaching occurs in places of greatest permeability and along joints in compact silty till. One of the best examples of this type of leached zone observed in the Norwood quadrangle was exposed temporarily in a pit at the north end of the middle drumlin in the northeast corner of the quadrangle. Limonite had been leached from the till along vertical cracks for a width of $1 / 2-3$ inches and to a depth of 5-10 feet. The leached till is light gray and looks like fresh till along cracks and where mottled. Invariably the leached till is bounded by yellowishbrown limonite-stained rims $1 / 4^{-1}$ inch wide, formed by redeposition of at least some of the limonite. Similar leached till has been observed by Kaye (1960, p. 348) in the Kingston quadrangle, Rhode Island.

The removal of iron from the leached zone was probably accomplished by organic solutions generated in the soil zone above. Some of the iron was redeposited as limonite below the leached zone as a coating on the surfaces of stones and mineral grains.

Uniform leaching and mottled leaching may occur independently or together. Where they occur together, uniform leaching grades downward into mottled leaching.

Although most of the stones found in the till and gravel of the Norwood quadrangle show only minor effects of weathering, a few partly decomposed stones can usually be found. Olivine diabase from Triassic dikes in the region weathers readily. Cobbles of this diabase have been found in many of the gravel pits in the quadrangle. Invariably the cobbles are weathered to such an extent that the exterior breaks off very easily in concentric layers, leaving a hard, less 
weathered core. The ease with which they break apart indicates that most of the weathering occurred after deposition of the gravel. According to Thwaites (1957 p. 62) "many geologists have sought to demonstrate that disintegrated stones had been altered before glaciation and were carried while frozen. In till it is difficult to refute such an explanation but when disintegrated pebbles occur in gravel, it is almost certain that they have been altered since deposition as they could not have been frozen all the time during water transportation." Some of these partly decayed diabase cobbles occur well below the surface. One cobble, $4-5$ inches in diameter, was found in place about 15 feet below the surface in the large gravel pit on the northeast side of the intersection of High Plain Street and Route 1 in the southwestern part of the quadrangle.

All the sand and gravel deposits and all but one exposure of till in the Norwood quadrangle show some oxidation and limonite staining to the bottom of the exposure. The one exception, an exposure at the north end of the middle drumlin in the northeast corner of the quadrangle, shows irregular remnants of fresh gray till of various sizes as much as 4 feet across, surrounded by oxidized brown limonitestained till, preserved about 20-25 feet below the original surface. The color contrast between the fresh till and the adjacent oxidized till makes the fresh till readily distinguishable.

Some of the stones in the gravel deposits are partly encrusted by secondary calcite. This calcite, probably a weathering product of igneous rocks, was leached from the upper part of the deposits and redeposited below, on the undersides of the stones, usually 5 feet or more below the surface.

\section{POSTGLACIAI DEPOSITS}

\section{SWAMP DEPOSITS}

Swamp deposits are accumulations of organic and inorganic meterial. These deposits occur wherever the water table is at or very close to the surface of the ground, generally in closed depressions in the land surface. Deposition of swamp material, which probably began when large masses of stagnant ice still remained in the area has continued to the present. The thickness of the deposits seems to be a function of the size of the swamp; small swamps with small watersheds contain very little sediment; large swamps, such as the one along the Neponset River which covers about 10 percent of the quadrangle, contain thicker deposits.

Swamp deposits in most places in the swamp along Neponset River are only a few feet thick. Borings made in the swamp between the Canton Airport and the north end of the swamp along Purgatory 
Brook are reported to have penetrated 1 to 28 feet of peat underlain by sand. Excavations for the Metropolitan District Commission sewer along the Neponset River uncovered only a few feet of peat except near Dedham Street where piling was required to support the sewer. Another ditch along the northeastern part of the unimproved road in Fowl Meadow exposed 6 inches to 2 feet of peat underlain by crossbedded sand containing some pebble gravel. Peat is well exposed in the banks of Purgatory Brook north of the Norwood Memorial Airport where about $2 \frac{1}{2}$ feet of brown peat containing abundant plant stems and roots overlies 2-3 feet of black to dark-brown finegrained peat. Only the top 1 foot of the fine-grained peat is exposed above the surface of Purgatory Brook. Sand and pebble gravel have been dredged from the bottom of the brook, and this fact indicates that the peat does not extend more than a foot or two below the water level. Some small light-gray lenses of diatomite were observed near the top of the upper peat.

\section{ARTIFICIAL FILL}

Deposits of artificial fill are shown on plate 2, particularly along the highways, railroads, and at the airports where they are thick and easily identified. Extensive filled areas also probably exist in the cities and towns, but they have not been shown on the map because they are difficult to distinguish. Small areas of fill around individual buildings were not mapped.

\section{MINERAL RESOURCES}

Deposits of sand and gravel are the most important mineral resources in the Norwood quadrangle. In addition there are deposits of peat, loam, and diatomite, and exposures of rock suitable for building stone and crushed stone. No stone has been quarried in recent years.

\section{SAND AND GRAVEL}

Sand and gravel deposits are widespread in the Norwood quadrangle, and pits have been worked in most of the deposits. Because of urban expansion, the sand and gravel areas available for exploitation have considerably diminished in recent years.

Knowledge of the compositional and structural characteristics of the different types of deposits helps locate sand and gravel of particular size ranges. Gravel is usually most abundant in the ice-channel deposits, kames, outwash plains, and kame terraces, and sand deposits are usually most abundant in the kame plains.

Most of the gravel in the quadrangle contains unweathered pebbles and cobbles of igneous rock and is of good quality. Some of the deposits in the southern part of the quadrangle, however, contain pebbles 
and cobbles of shale and friable sandstone from the Wamsutta Formation of the Norfolk basin and are therefore of poorer quality.

Ice-channel deposits.-Ice-channel deposits are usually good sources of coarse bouldery gravel, and parts of these deposits in the quadrangle have been worked.

Kames.-Kames show considerable variation in the relative amount and coarseness of the sand and gravel that they contain. Boulders, some of them of large size, are common. The large kame area in the southeastern corner of the quadrangle is exceptional in that it contains chiefly sand and pebble gravel. The kame area in the north-central part of the quadrangle, between Norwood and Oakdale, contains abundant coarse gravel in places and has been worked extensively for gravel on both sides of Route 128 .

Outwash plains.-The sand and gravel deposits of all the outwash plains mapped in the quadrangle are becoming inaccessible because of housing developments and factories. The outwash plains that underlie Dedham and Readville are entirely in urban areas. The outwash plain on the southwest side of Westwood and the one in the southern part of Norwood have been sites of much residential construction in recent years. The outwash plain at Westwood has been worked for gravel on the west side of Buckmaster Pond; this deposit is composed of horizontally stratified interbedded pebble and cobble gravel containing some coarse sand lenses and a few small boulders. Several abandoned pits on the west side of Route 1 in the outwash plain in the southern part of Norwood exposed sand and much pebble gravel containing pebbles from $1 / 2$ to 2 inches in greatest dimension.

Kame terraces.-Kame terraces are important sources of sand and gravel in the Norwood quadrangle; they resemble outwash plains in composition but, unlike the outwash plains, commonly contain scattered boulders. The kame terraces in the northern part of the quadrangle are in urban areas where a pit site would be difficult to find. The most extensive kame terraces occur in the southwest corner of the quadrangle in the vicinity of Walpole Heights. These terraces are composed mainly of pebble gravel and some cobble gravel, sand, and scattered boulders. In places, sand is more abundant than gravel. Although sand and gravel pits have been opened in many places in these kame terraces, most of the deposits are small, and the gravel is no longer being extracted. The largest pit is on the north side of High Plain Street about 500 feet east of Route 1. This pit exposes well-bedded pebble and cobble gravel containing some sand and a few small boulders. The kame terrace on the west side of Germany Brook west of Norwood contains a large sand and gravel pit that exposes chiefly pebble and cobble gravel in the upper $6-15$ feet; sand is probably 
abundant below. The gravel of this deposit was nearly depleted in 1961.

Kame plains.-The kame plains in the Norwood quadrangle are glacial deltas having horizontally bedded topset beds 2-10 feet thick composed of pebble and cobble gravel underlain by foreset beds composed of sand and some interbedded gravel. Several large kane plains border the Neponset River valley, and smaller ones occur in the southeast and north-central parts of the quadrangle.

The four largest kame plains that border the Neponset River valley were deposited over bedrock ridges and knobs and are generally thin over much of their extent. The kame plain crossed by Canton Street in Westwood ranges from about 3 to 15 feet in thickness at the large sand and gravel pit at its north end. The underlying till is exposed in the floor of the pit and in parts of the pit face. The kame plain here is composed of sand with subordinate pebble and cobble gravel. Most of the gravel is in the top few feet of the deposit. Till and bedrock have been found in places in the floor of gravel pits on the southeast side of this kame plain, northeast of Canton Street. Pebble and cobble gravel are more abundant in these pits than in the pit at the north end of the deposit. Sand is also exposed in the southwestern part of this kame plain.

The high ridge-shaped kame plain crossed by Route 1 northeast of Norwood is composed mostly of sand with some pebble and cobble gravel, particularly near the top of the deposit. Several pits have been worked in this deposit, and the northwest end, west of Route 1, has been almost entirely excavated.

The kame plain crossed by Neponset Street south of the Norwood airport has a large abandoned gravel pit at its south end near the Neponset River. Till and bedrock are exposed on the floor of the pit, showing that the kame plain was only 10-15 feet thick. Other smaller pits are to the north and northwest. A residential area has been built on most of this kame plain.

The large kame plain crossed by Dedham Street, in the east-central part of the quadrangle, has large sand and gravel pits at its northwest end near the railroad and on the northeast side of Dedham Street. Gravel is abundant in the top few feet, but there is more sand than gravel in both pits.

The large kame plain crossed by Canton Street southwest of Canton has been built around rock knobs, several of which project through the deposit. Only a few small pits have been worked in this deposit, and its composition and structure are not well known. Several test pits on the east side of the rock knobs, at the northeast end of the deposit, exposed pebble and cobble gravel to a depth of about 8 feet. The 
small pit south of Chestnut Tree Cemetery and the railroad-cut 1,000 feet farther south near Sawmill Pond expose sand and pebble gravel containing scattered cobbles. The Sharon Memorial Park Cemetery covers a large tract near the middle of the kame plain. Pit sites, however, may be found elsewhere.

The small kame plains in the southeastern corner of the Norwood quadrangle have been worked for sand. Pits in the deposits expose topset beds a few feet thick composed mainly of gravel underlain by foreset beds composed of sand and some interbedded pebble gravel.

Delta outwash plain.-The sand and the gravel of the delta crossed by Route 128 at the eastern edge of the quadrangle were worked in a large pit. This pit, now abandoned and graded, formerly exposed topset beds 5-10 feet thick composed of about 80 percent pebble gravel, 10 percent cobble gravel, and 10 percent sand, underlain by foreset beds composed of interbedded sand and pebble gravel containing a few scattered cobbles.

Neponset River valley deposits.-Borings and sewer excavations have shown that sand and some gravel underlie the Neponset River and Purgatory Brook swamps in places to considerable depths. Borings at the sites of the bridges over the railroad in the swamp on the relocation of Route 128 penetrated mostly sand and some gravel to a maximum depth of 142 feet. Because housing developments and other uses are rapidly diminishing the available pit sites in the other deposits of the quadrangle, it may become feasible to dredge sand and gravel for commercial use from the swamp area.

The thickest deposits are in the lower buried parts of the valley floor under the Neponset River and Purgatory Brook swamps. The estimated locations of the axes of these buried channels are shown on the surficial geologic map (pl. 2). Excepting the buried channels, bedrock under the swamp area appears relatively shallow and is probably overlain by only a few feet to a few tens of feet of deposits such as peat, sand, and gravel. Because of these variations and because of the abundance of fine sand, the thickness and composition of the deposits should be tested before a site is selected for a pit.

\section{LOAM}

Loam has been stripped from the surface in many places in the quadrangle. Much of the fine material of the loam is wind-deposited silt. The loam occurs both on till and on sand and gravel deposits, and it ranges in thickness from a few inches to a few feet. The greatest thicknesses are generally found in depressions. 
Thick deposits of peat occur in places in the Neponset River valley swamp, but little is known of the thickness of the peat in the other swamps of the quadrangle. Borings made in the Neponset River valley swamp, between the Canton Airport and the north end of the Purgatory Brook part of the swamp, are reported to have penetrated 1-28 feet of peat underlain by sand. The thickest peat $(28 \mathrm{ft}$ ) was found a short distance north of the Norwood Memorial Airport. At the airport the peat averaged only about 3 feet in thickness. In most places in this swamp the peat probably does not exceed 5 feet in thickness.

Two types of peat are exposed in the banks of Purgatory Brook about 2,500 feet southeast of where Route 1 crosses the brook. The top $21 / 2$ feet is brown fibrous peat containing abundant roots and stems. This fibrous peat is underlain by a layer of fine-grained black to darkbrown peat $1 \frac{1}{1} 2-21 / 2$ feet thick that does not have many distinguishable plant fibers and stems. Except where closely examined, this peat looks like mud. The Massachusetts Peat and Fuel Co. is reported to have dug peat for a short time in the vicinity of the Norwood Memorial Airport about 1930. The peat, which was dug from a pit 25 feet deep near Route 1 on the north side of the airport, was compressed and sold for fuel. Peat from this area has also been sold for horticultural uses.

\section{DIATOMITE}

Diatomite, composed of the opaline silica shells of microscopic aquatic plants, is reported to have been dug from the Neponset River swamp between 1937 and 1941 by the New Hampshire Diatomite Co. According to John L. Rizzo (oral commun., 1950), the superintendent of the field operations, the diatomite was found in pockets under 1-11/2 feet of peat on the west side of the Neponset River, about half a mile southwest to half a mile northeast of Neponset Street. The pockets worked averaged about 30 inches in thickness and did not exceed 100 feet in length.

About 2,500 tons of undried diatomite was shipped to Portsmouth, N.H., for processing for use in silver polish. Before the diatomite was processed, organic matter made it gray to black. Diatomite can still be found at some of the old pits about 1,750 feet southwest of Neponset Street.

\section{BUILDING STONE}

The Norwood quadrangle contains several types of igneous rock that are classed commercially as granite; these include the Dedham Granodiorite, the Westwood Granite, the Sharon Syenite, the fine- 
grained granite associated with the Sharon Syenite, and the Blue Hill Granite Porphyry.

The Dedham Granodiorite is a coarse-grained pale-pink rock with a very low content of iron-bearing minerals; it does not discolor upon weathering. In some places the granodiorite is so fractured that it is not suitable for building stone, but in other places the joints are spaced at least several feet apart. A small amount of this rock has been quarried south of Canton, about 1,500 feet east of the intersection of Bay Street and Central Street.

The Westwood Granite is finer grained but in most places resembles the Dedham Granodiorite in color. Some of the granite in the vicinity of the intersection of Routes 128 and 109, in the north-central part of the quadrangle, is a distinctive pink. During the latter half of the 19th century, this pink granite was quarried for dimension stone in three small quarries that are now filled. One, 15-20 feet deep and about 75 feet long, was located at the intersection of Route 109 and the southeastbound lanes of Route 128. Another smaller quarry was located at the intersection of Route 109 and the northwestbound lanes of Route 128. The third quarry was about 900 feet southwest of the first. Stone from these quarries was used for the construction of several buildings in Dedham, including St. Paul's Episcopal Church (1857), Memorial Hall (1867), St. Mary's Church and rectory (1880), the public library, and the old Bullard residence. This stone was also used in Trinity Church at Copley Square in Boston. This pink granite occurs in a small area and is no longer available for quarrying because of highway construction. The common variety of the Westwood Granite is more widespread and could be quarried. The seamfaced granite, quarried south of East. Weymouth about 111/2 miles east of the Norwood quadrangle, is of this variety.

\section{CRUSHED STONE}

The Mattapan Volcanic Complex, which is widespread in the northwestern part of the quadrangle, is a good source for crushed stone. Similar rock has been quarried extensively in Malden, Lynn, and elsewhere in eastern Massachusetts.

The Westwood Granite has been quarried for crushed stone at the north edge of Norwood and 1,700 feet north of the intersection of Route $1 \mathrm{~A}$ and the northwestbound lanes of Route 128. The other granitoid rocks have not been used for this purpose. The Salem Gabbro-Diorite is satisfactory, but because of its limited distribution, it has not been quarried in the Norwood quadrangle, although it has been quarried elsewhere in eastern Massachusetts. The Pondville Conglomerate and Wamsutta Formation in general are not sufficiently homogeneous, strong, or durable for most uses of crushed stone. 


\section{GEOLOGIC HISTORY}

Interpretation of the geologic history of the Norwood quadrangle is hindered by an inadequate rock record, and because of this missing record the Precambrian history of the area is largely unknown. The metarhyolite and amphibolite exposed in a few places in Canton in the southeastern part of the quadrangle may be Precambrian in age and, if so, are evidence of igneous activity. The northwest strike and the higher rank of metamorphism of these rocks indicate an orogeny, possibly in the Precambrian, that had stresses oriented nearly at right angles to those of the later orogenies.

Early in the Paleozoic Era, probably in Late Cambrian time after erosion had reduced the relief, a shallow sea spread over eastern Massachusetts. Clay and sand were deposited in the sea to form the Green Lodge Formation of Rhodes and Graves (1931). The phyllite north of East Walpole is derived from sediments that were probably deposited at the same time.

At some time after the formation of the amphibolite and metarhyolite and before the extrusion of the Mattapan Volcanic Complex, the Salem Gabbro-Diorite, Newburyport Quartz Diorite, Dedham Granodiorite, and the Westwood Granite were intruded successively throughout the quadrangle. These intrusions were so extensive that they destroyed most of the older rocks; they were followed, possibly in the Devonian or Carboniferous Period, by the intrusion of diorite, followed by the Sharon Syenite, fine-grained granite, and aplite in the southern part of the quadrangle.

After an interval of erosion, the rhyolitic lavas and pyroclastic rocks of the Mattapan Volcanic Complex were erupted over much of the northern part of the quadrangle, probably during the Devonian or the Carboniferous Period. Near the close of this volcanic episode, rhyolite was intruded and formed dikes and small irregular bodies in the older plutonic and volcanic rocks. After the eruption of the Mattapan Volcanic Complex, the Blue Hill Granite Porphyry was injected in the eastern part of the Norwood quadrangle, probably during Late Devonian or Mississippian time.

During the latter part of the Paleozoic Era, in the Carboniferous Period, basins formed, and nonmarine deposits of gravel, sand, and clay accumulated to form the Roxbury Conglomerate of the Boston basin and the Pennsylvanian Pondville Conglomerate and the Wamsutta Formation of the Norfolk basin. The coarseness of the gravel. in the Pondville Conglomerate and the Roxbury Conglomerate indicates that during their deposition the area had significant relief, but this relief was much less by the time the red sand and mud of the Wamsutta Formation were deposited in the Norfolk basin. 
The Norfolk basin sedimentary rocks were folded and faulted during the late Paleozoic by great earth stresses that formed the original Appalachian Mountains in the eastern part of the United States. Most of the folds, faults, joints, and shear zones in the rocks of the quadrangle probably originated at this time. Following this orogeny, in the Triassic Period of the Mesozoic Era, diabase dikes having a prevailing north-south strike were intruded as the last igneous activity. Some additional fracturing and faulting may have occurred at this time.

As post-Pennsylvanian to pre-Quaternary sedimentary rocks have not been found in the Norwood quadrangle or nearby, it is possible that the quadrangle was exposed to erosion during most or all of postCarboniferous to pre-Quaternary time. Mesozoic or Tertiary sediments may have been deposited as far north as the Norwood quadrangle and subsequently eroded, although some could be preserved beneath Quaternary deposits.

The present topography was formed during the Quaternary Period and the latter part of the Tertiary Period. The buried valleys originated by stream erosion before the last glaciation, when the sea level was lower than at present.

The Pleistocene Epoch of the Quaternary Period began about a million years ago when ice sheets spread over northern North America. Although there were several ice advances, definite evidence for only one was found in the Norwood quadrangle. Kaye (1961), however, gave evidence for multiple glaciation in the Boston area. The last ice sheet, generally considered to belong to the Cary Stade of the Wisconsin Glaciation, eroded the land surface somewhat as it advanced but did not greatly modify the stream-eroded topography. Preexisting sediments in the buried valleys may have been only partly eroded.

As the ice sheet thinned during the closing stages of the glacial advance, ground moraine deposited beneath the ice was molded against bedrock knobs and hills. Continued thinning caused the ice to become stagnant in a broad zone along the margin of the ice sheet and to melt away gradually without the formation of recessional moraines. Because the drainage divide is south of the Norwood quadrangle in the northern part of the Mansfield quadrangle, the melt-water drainage through the divide occurred first at an altitude of about 250 feet and later at an altitude of about 220 feet, and still later at lower altitudes as lower outlets were opened to the north. While the glacial ice blocked the northward drainage, the glacial melt water became ponded; the extensive kames and kame plains in the southeastern corner of the quadrangle were formed at this time, and the high-level kame terraces and kames around Walpole Heights were also probably formed at this 
time. Continued melting of the ice uncovered the tops of hills and ridges along the Neponset River valley, and these exposed land areas became ponded areas within the ice. Deposits in the ponds resulted in the formation of large kame plains. Further melting caused these lakes to be drained and opened lower areas in the valleys in which the kames and kame terraces formed. The outwash plains that occupy broad low areas were among the last of the glacial outwash deposits to form. As the glacial ice melted from the Neponset River and Purgatory Brook valleys a lake formed in them and became filled with clay, sand, and gravel. The inflow of sand and gravel gradually ceased, and a deposit of peat was formed at the surface in the swamp that remained. Also during the final stages of deglaciation, before vegetation covered the area, a thin layer of windblown silt (loess) was deposited. Since the glaciation, the deposits have been modified very little.

\section{REFERENCES CITED}

Bascom, Florence, 1900, Volcanics of Neponset Valley, Massachusetts: Geol. Soc. America Bull., v. 11, p. 115-126.

1912, The petrographic province of Neponset Valley, Massachusetts : Acad. Nat. Sci. Philadelphia Jour., 2d ser., v. 15, p. 129-161.

Bell, K. G., 1948, Geology of the Boston metropolitan area: Ph.D. thesis, Massachusetts Inst. Technology.

Billings, M. P., 1929, Structural geology of the eastern part of the Boston Basin: Am. Jour. Sci., v. 18, no. 104, p. 97-137.

Bottino, M. L., 1963, Whole-rock $\mathrm{Rb}-\mathrm{Sr}$ studies of volcanics and some related granites-11th Ann. Prog. Rept. for 1963: U.S. Atomic Energy Comm., NYO-10517, p. 65-84.

Bottino, M. L., Pinson, W. H., Jr., Fairbairn, H. W., and Hurley, P. M., 1963, Whole-rock $\mathrm{Rb}-\mathrm{Sr}$ ages of some Paleozoic volcanics and related granites in the northern Appalachians [abs.] : Am. Geophys. Union Trans., v. 44, p. 111.

Chayes, Felix, 1952, The finer-grained calcalkaline granites of New England: Jour. Geology, v. 60, no. 3, p. 207-254.

Chute, N. E., 1940, Preliminary report on the geology of the Blue Hills quadrangle, Massachusetts: U.S. Geol. Survey and Massachusetts Dept. Public Works Co-op. Proj., Bull. 1, 52 p.

1950, Surficial geology of the Brockton quadrangle, Massachusetts: U.S. Geol. Survey Geol. Quad. Map GQ-6.

1959, Glacial geology of the Mystic Lakes-Fresh Pond area, Massachusetts : U.S. Geol. Survey Bull. 1061-F, p. 187-216.

Clapp, C. H., 1910, The igneous rocks of Essex County, Massachusetts [abs. of thesis] Massachusetts Inst. Technology, $12 \mathrm{p}$.

- 1921, Geologs of the igneous rocks of Essex County, Mass.: U.S. Geol. Survey Bull. 704, $132 \mathrm{p}$.

Clapp, F. G., 1904, Relations of gravel deposits in the northern part of glacial Lake Charles [Massachusetts] : Jour. Geology, v. 12, p. 198-214.

Crosby, I. B., 1934, Evidence from drumlins concerning the glacial history of Boston basin: Geol. Soc. America Bull., v. 45, p. 135-158.

1939, Ground water in the preglacial buried valleys of Massachusetts:

New England Water Works Assoc. Jour., จ. 53, no. 3, p. 372-383. 
Crosby, W. O., 1889, Relations of the pinite of the Boston Basin to the felsite and conglomerate: Technology Quart. (Massachusetts Inst. Technology), v. 2. p. 248-252.

1900, Geology of the Boston basin: the Blue Hills complex: Boston Soc. Nat. History Occasional Papers 4, v. 1, pt. 3, p. 289-563.

1905 , Genetic and structural relations of the igneous rocks of the lower Neponset Valley, Massachusetts: Am. Geologist, v. 36, p. 34-47, 69-83; Technology Quart. (Massachusetts Inst. Technology), v. 18, p. 386-409, 1905.

Crosby, W. O., and Grabau, A. W., 1896, Glacial lakes of the Boston basin [abs.] : Am. Geologist, v. 17, p. 128-130.

Davis, W. M., 1895, The physical geography of southern New England: Natl. Geog. Soc. Monthly 1, no. 9, p. 269-304.

Denny, C. S., 1958, Surficial 'geology of the Canaan area, New Hampshire: U.S. Geol. Survey Bull. 1061-C, p. 73-100.

Dott, R. H., Jr., 1961, Squantum "Tillite," Massachusetts--evidence of glaciation or subaqueous mass movements?: Geol. Soc. America Bull., v. 72, no. 9, p. 1289-1305.

Dowse, A. M., 1948, Geology of the Medfield-Holliston area, Massachusetts : Ph. D. thesis, Radcliffe College.

1950, New evidence on the Cambrian contact at Hoppin Hill, North Attleboro, Massachusetts: Am. Jour. Sci., v. 248, no. 2, p. 95-99.

Emerson, B. K., 1917, Geology of Massachusetts and Rhode Island: U.S. Geol. Survey Bull. 597, 289 p.

Fuller, M. L., 1904, Ice retreat in glacial Lake Neponset and in southeastern Massachusetts: Jour. Geology, v. 12, p. 181-197.

Hansen, W. R., 1956, Geology and mineral resources of the Hudson and Maynard quadrangles, Massachusetts: U.S. Geol. Survey Bull. 1038, 104 p.

Hartshorn, J. H., 1958, Flowtill in southeastern Massachusetts: Geol. Soc. America Bull., v. 69, p. 477-481.

Hurley, P. M., Fairbairn, H. W., Pinson, W. H., and Faure, G., 1960, K/A and $\mathrm{Rb} / \mathrm{Sr}$ minimum ages for the Pennsylvanian section in the Narragansett basin: Geochim. et Cosmochim. Acta, v. 18, p. 247-258.

Ilsley, Ralph, 1934, Structural geology of eastern Massachusetts: Ph. D. thesis, Massachusetts Inst. Technology.

Jahns, R. H., 1951, Surficial geology of the Mount Toby quadrangle, Massachusetts: U.S. Geol. Survey Geol. Quad. Map GQ-9.

Judson, S. S., Jr., 1949, The Pleistocene stratigraphy of Boston, Massachusetts and its relation to the Boylston Street Fishweir, in Johnson, Frederick, ed., The Bolyston Street Fishweir II: R. S. Peabody Found. for Archaeology Papers, v. 4, no. 1, p. 7-48.

Kaye, C. A., 1960, Surficial geology of the Kingston quadrangle, Rhode Island: U.S. Geol. Survey Bull. 1071-I, p. 341-396.

_ـ 1961, Pleistocene stratigraphy of Boston, Massachusetts : U.S. Geol. Survey Prof. Paper 424-B, p. B-73-B-76.

LaForge, Laurence, 1932, Geology of the Boston area, Massachusetts: U.S. Geol. Survey Bull. 839, $105 \mathrm{p}$.

Loughlin, G. F., 1911, Contribution to the geology of the Boston and Norfolk basins, Massachusetts: I. The structural relations between the Quincy granite and the adjacent sedimentary formations: Am. Jour. Sci., 4th ser., v. 32, p. 17-32. 
Loughlin, G. F., and Hechinger, L. A., 1914, An unconformity in the Narragansett basin of Rhode Island and Massachusetts: Am. Jour. Sci., 4th ser., v. 38, p. $45-64$.

Power, W. R., Jr., 1957, Surficial geology of the Slocum quadrangle, Rhode Island : U. S. Geol. Survey Geol. Quad. Map GQ-106.

Quinn, A. W., and Oliver, W. A., Jr., 1962, Pennsylvanian rocks of New England, in Branson, C. C., ed., Pennsylvanian System in the United States: Tulsa, Okla., Am. Assoc. Petroleum Geologists, p. 60-73.

Ramo, Alan, and Fairbairn, H. W., 1963, Preliminary age study of the Dedham granitic rocks-11th Ann. Prog. Rept. for 1963: U.S. Atomic Energy Comm., NYO-10517, p. 53-54.

Rhodes, E. J., and Graves, W. H., Jr., 1931, A new Cambrian locality in Massachusetts: Am. Jour. Sci., v. 22, p. 364-372.

Ross, C. S. and Smith, R. I.., 1961, Ash-flow tuffs-Their origin, geologic relations, and identification: U.S. Geol. Survey Prof. Paper 366, 81 p.

Shaler, N. S., Woodworth, J. B., and Foerste, A. F., 1899, Geology of the Narragansett basin : U.S. Geol. Survey Mon. 33, 402 p.

Smith, H. T. U., and Fraser, H. J., 1935, Loess in the vicinity of Boston, Mass.: Am. Jour. Sci., v. 30, n. 175, p. 16-32.

Thwaites, F. T., 1957, Outline of glacial geology: Ann Arbor, Mich., Edward Bros., $142 \mathrm{p}$.

Turner, F. J., and Verhoogen, John, 1960, Igneous and metamorphic petrology, 2d ed. : New York, McGraw-Hill Book Co., $694 \mathrm{p}$.

Upson, J. E., and Spencer, C. W., 1961, Some geologic features of bedrock valleys of the New England coast: New York Acad. Sci. Trans., ser. 2, v. 24, no. 1, p. $36-45$.

Webber, G. R., Hurley, P. M., and Fairbairn, H. W., 1956, Relative ages of eastern Massachusetts granites by total lead ratios in zircon : Am. Jour. Sci., v. 254, no. 9, p. 574-583.

Woodworth, J. B., 1894, Carboniferous fossils in the Norfolk County basin [Mass.] : Am. Jour. Sci., 3d ser., v. 48, p. 145-148. 



\section{INDEX}

[Italic page numbers indicate major references]

A

B

Bedding, Wamsutta Formation

Bedrock, geology. topographic control

Bell, K. G., quoted.

Blue Hill Granite Porphyry, age.

commercial granite.

description.

cmplacement

pebbles missing in Roxbury Conglomerate..

Blue Hills quadrangle, Blue Hill Granite Porphyry.

kame field

Sharon Syenite

Westwood Granite

Blue Star Memorial Highway

Brockton quadrangle, kame field

Westwood Granite

Brookline Conglomerate, correlation with description Pondville Conglomerate...........

of Roxbury Conglomerate.

Building stone, description....................

Buried Neponset River valley, axis............

Buried tributary........................... 45,4

Buried valleys, description.................... glacial erosion.

\section{C}

Cambridge Slate.

Carboniferous age, sedimentary rocks.
Carboniferous dikes, alteration................ $\quad 35$

Carboniferous Period...................... $\quad 69$

Carboniferous rocks, description.............. $\$ 0$

Cary Stade, Wisconsin Glaciation............ 70

Charles River............................... 2

Clay . . . . .

Columnar jointing, Triassic dikes............ 44

Cretaceous Period, topography ............. 3

Crevasse fillings, defined................... 52

Crossbedding, in ice-channel deposit.......... 53

in kame terraces......................... 54

Crushed stone, description. . . ............. 68

\section{$\mathrm{D}$}

Dedham, outwash plain ...................... 58

Dedham Granodiorite................. 6, 12,39,69

age ................................. 8, 14, 20

commercial granite. . . . . .

constituents.............................. 13

contact with pyroclastic rocks............. 26

cut by faults............................... 40

description............................ 18

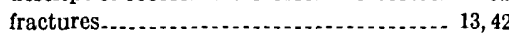

fragments............................... 18

in pyroclastic rock................... 26

gray felsites............................... 25

intrusion.............................. 4

slickensides................................. 44

Stony Brook variety ...................... $\quad 19$

Dedham, Mass., type locality of Dedham Granodiorite.................. 12

Delta outwash plain, description............ $\quad 57$

sand and gravel deposits.................. $\quad 60$

Deposition, Norwood quadrangle............ 44

swamp material........................ 62

Devonian. ... . . . . . . . 69

Diabase dikes, Carboniferous age............. 35

Diatomite, description........................ 67

Dikes. . . . . .

Dedham Granodiorite.................. 35

description............................... 34

Mattapan Volcanic Complex.............. $\quad 35$

Triassic olivine diabase................. 30

Diorite .

description............................. 21

correlation with Wamsutta Formation.... $\$ \$ 4$

Dorchester Slate Member, Roxbury Con-

43
4 Dowse, A. M., quoted ................... 23, 24 
Drumlins, description

Norwood quadrangle

E

Eolian deposits, description

Erosion

post-Carboniferous Period

pre-Quaternary.

remnants.

Eskers, defined.

Estuarine deposits, Neponset River buried

Extent of area

$$
\text { valley .- }
$$

\section{F}

Faults.

description

horizontal displac

hite dikes, description

Fine-grained granite, Sharon Syenite.

Flowtill, description

Norwood quadrangle.

Folds.

description

structural geology

Fossils

G

Geologic history, general

Glacial deposits, topographic control unstratified deposits

Glacial erosion, buried valleys description

Glacial outwash deposits

Glaciation, effect on drainage.

effect on topography .

Pleistocene Epoch.

Quaternary

Gravel .

Gray felsites, description

Green Lodge Formation.

description

Late Cambrian age

phyllite

Upper Cambrian age

Ground moraine, described

streamlining.

thickness.

Ground moraine till, age

\section{HI}

High-level kame terraces.

Holliston quadrangle, Dedham Granodiorite Hydrothermal solutions, alteration agents....

\section{I}

Ice-channel deposits, description sand and gravel

Igneous rocks, carboniferous or older description.

Iron, removal from leached zone

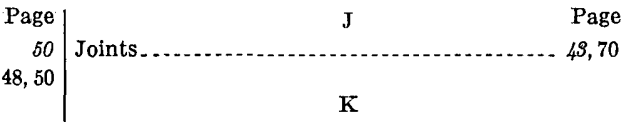

Kame field, description

60 Kame plains......................... 55, 70,71

44,69

70

Kames. deposited as deltas........................ 55 description............................. 55 elevation...... 56

sand and gravel deposits. ................ 65

Kame terraces, described................... 54 formed . . . 71 sand and gravel deposits . ................ 64 description................................ 51 sand and gravel deposits . .............. 64

\section{$\mathbf{L}$}

Lamination, in metarhyolite............... 6

Late Cambrian age........................... 69

Green Lodge Formation............... $\gamma$

Leached zones............................ 61 Limonite, removal from till and gravel deposits........................... 61

Limonite staining, factors affecting .......... 60

Loam, description............................. 66

Location of area

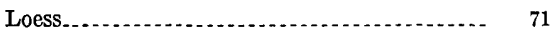

\section{M}

Mafic dikes, age . . .......................... 34

Mafic rocks, alteration.................... 38

Salem Gabbro-Diorite.................. 8

Mansfield quadrangle....................... 70

Marlboro Formation ................... 4

age of folding................... 40

folding .................................. 39

fragments . . . .

Mattapan Volcanic Complex . . . . . . . . . . . . 15, 69

age.......................................... 29

cut by faults........................... 40

description................................ 23

Devonian or Carboniferous age........... 24

gray felsites................................ 25

Neponset River valley area. . . ........... 24

pebbles, Brookline Conglomerate Member. $\quad 29$ quarried for crushed stone............ 68

Medfield quadrangle, Dedham Granodiorite.. $\quad 13$

Westwood Granite. ..................... 14

Mesozoic Era................................... 70

Metadiorite, Newburyport Quartz Diorite... 11

Metamorphic rocks, pre-Carboniferous...... 4

Metamorphism, contact.................... 38

description ............................ 37

regional............................... 38

Metarhyolite....................... 4,69

description. . . . . . . .

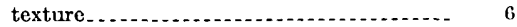

Mineral resources, description................ 69

Mississippian time........................... 69

61 Mount Toby quadrangle, delta outwash plain. 58

s. 
Needham upland, igneous rocks.

Neponset River.

buried valley, constituents

thickness.

swamp, sand and gravel deposits

valley area, Mattapan Volcanic Complex. valley deposits, sand and gravel deposits.-

Newburyport Quartz Diorite

age.

chilled contacts

description.

(n)

gradational relationship metadiorite

Newton quadrangle, volcanic rocks.

Westwood Granite

Nonporphyritic amphibolite, described basin.

Mattapan Volcanic Complex missing..... Pondville Conglomerate in ................ sedimentary stratum. ................... Wamsutta Formation in

Norwood, outwash plain..................... Norwood quandrangle, delta outwash plain... drumlins.

\section{$\mathrm{O}$}

Orogeny, possibly Precambrian

Triassic Period.

Outwash plains

description.................................... sand and gravel deposits.

$P$

Paleozoic Era description.

Pegmatitic Salem Gabbro-Diorite, characteristics -

Pennsylvanian age, Pondville Conglomerate.. Wamsutta Formation

Pennsylvanian sedimentary rocks, Pondville Conglomerate.

Phyllite, description

Green Lodge Formation

Pink porphyritic rhyolite, description.......

Pleistocene Epoch, evidence of glaciation.....

Pondville Conglomerate

Carboniferous age. . ............................ correlation with Brookline Conglomerate. folding.

lower member .................................. matrix

Pennsylvanian sedimentary rocks

shear zones.

terminated by fault

thickness

upper member.

Wamsutta Formation

Porphyritic amphibolite, described

Post-Carboniferous Period, erosion
Postglacial deposits, description.

Post-Pennsyl ranian sedimentary rocks

Precambrian history of area, largely unknown. 69

Pre-Quaternary, erosion..................... $\quad 70$

Previous work in quadrangle.................

Purgatory Brook swamp, sand and gravel de-

Pyroclastic rocks.

description. . . . . .

\section{Q}

Quadrangle, kame field....................... 52

Quartzite, Green Lodge Formation........... 7

Quaternary, glaciation...................... 44

unconsolidated sediments................. 3

Quincy Granite, age...................... 21, 28

$\mathrm{R}$

Readville, outwash plain .................. 58

Recessional moraines, lack................... $\quad 70$

Reverse faults, Norfolk basin................ 41

Rhyolitic lavas............................. 69

Roxbury Conglomerate.................. $89,80,69$ bordered by faults...................... 40, 42

Boston basin............................. 33

description............................... 28

Devonian or Carboniferous age.......... 4 sedimentary rocks....................... 28

\section{$\mathrm{S}$}

Salem Gabbro-Diorite.................... 12, 68, 69 contact with Dedham Granodiorite....... 10 description............................... 8

fragments............................. 18

gradational relationship................ 12

intrusion.............................. 4

intrusion breccia....................... 16

medium-grained variety ................. 10

Sand . . . . . . . . . .

Sand and gravel, description................. 59,68

Sedimentary rocks, post-Pennsylvaniall..... 70

pre-Quaternary ......................... 70

Roxbury Conglomerate.................. 28

Seismic measurements, U.S. Geological Survey ...............................

Seismic traverses, U.S. Geological Survey .... 58

Sharon Syenite............................... 69

associated with aplite.................... 22

commercial granite.

description.......................... 22

dike......................................... 21

finc-grained granite........................ 22

igneous rocks........................... 20

shear cracks........................... 41

Sharon upland, igneous rocks................. 4

Shear zones................................... 70

Slickensides. . .................................. 44

Squantum Tillite Member, description....... $\quad 30$

Roxbury Conglomerate............... 29

Stony Brook fault......................... 31

along Neponset Valley.................. $\quad 40$ 
Stony Brook Reservation, Dedham Granodi-

Stoughton Bay, glacial Lake Neponșet. . . .

Page

Stratified deposits, description.

Striations

Strike and dip. joints

Structural geology, folds.

Surficial geology, descriptic

Swamp deposits, description

Swamps

\section{$\mathrm{T}$}

Tertiary deposition.

Tertiary Period, uplift.

Thickness, ground moraine.

peat.

swamp deposits

(n)

Thuites, F T quoted

Till, local derivation.

Neponset River buried valler

surface of ground moraine. . -

Till deposits, ground moraine

Topographic history

Topography .

Triassic dikes, columnar jointing

Type locality, Westwood Granite

$\mathrm{U}$

Unclassified sand and gravel deposits, description.

Unconsolidated sediments, buried valleys.....

U.S. Geological Survey, seismic measurement..

seismic traverses.

Unstratified deposits, glacial deposits

\section{V}

Varved lake clays, description

Ventifacts.
12
W

Page

Wamsutta Formation. ...................... 68 carboniferous age, Pennsylvanian age contact with Pondville Conglomerate...... $\quad 33$ correlation with Dorchester Slate Member......................... 34 description.................................. $\$ 2$

folding . . . .

jointing................................... 43

Norfolk basin ........................ 33, 69

Pennsylvanian age. . . . . . . . .

shear zones. ............................ 42

stratigraphic section....................... 33

Weathering, charactersitic of glacial drift..... 60

Westwood, outwash plain.................. 58

Westwood Granite . . . .

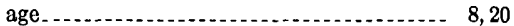

commercial granite.

common variety....................... 15

contact with pink porphyritic rhyolite.... $\quad 26$

contact with pyroclastic rocks............ 26

contact with Salem Gabbro-Diorite....... 10

contaminated 16

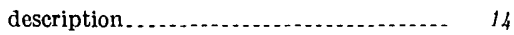

four varieties. ...................... 15

fragments in pyroclastic rock . . . . . . . . . . $\quad 26$

gray felsites................................ 25

hybrid variety ................ 16

intrusion breccia........................ 4

matrix of breccia....................... 18

minerals................... 15

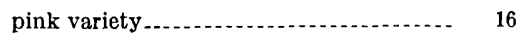

porphyritic variety ................... 15

quarried for crushed stones.............. 68

Winsconsin Glaciation, Cary Stade.......... $\quad 70$

Y

Yankee Division Highway (State Route 128), through quadrangle............. 2 